\title{
Does more unemployment cause more fear of unemployment?
}

\author{
Vladimir Gimpelson ${ }^{1 *}$ and Aleksey Oshchepkov ${ }^{2}$
}

\footnotetext{
* Correspondence: vladim@hse.ru ${ }^{1}$ Centre for Labor Market Studies, National Research University Higher School of Economics, IZA, Moscow, Russia

Full list of author information is available at the end of the article
}

\begin{abstract}
Using the Russian Longitudinal Monitoring Survey data, the paper examines Russian workers' fear of unemployment under different economic and labor market conditions during the last 15 years. We employ two alternative measures for this fear. The first one looks at the workers' fear of losing their current jobs, while the second deals with the fear of not finding relevant re-employment in case of displacement. In order to get the best possible measurement of unemployment for those local and social environments where our respondents live and work, we design unemployment rates for narrowly defined regional and demographic (peer) groups. Estimating ordered probit models for both fear measures, and controlling for various worker and job characteristics, we do not find significant causal effects of unemployment on these fears in most of our specifications. These results are robust to exclusion of potentially endogenous variables; they hold for different periods, subsamples, and levels of job security. Moreover, our simulations show that even a large increase in the unemployment rate has little impact on conditional probabilities of expressing a strong or weak fear of unemployment. These results suggest that the high level and persistence of fear of unemployment in Russia may be caused by non-economic factors.

Jel codes: $121, \mathrm{~J} 12, \mathrm{~J} 620$

Keywords: Fear of unemployment, Job insecurity, Russia
\end{abstract}

"There are other structures that operate, to a large degree, independently of the reasoning process. And when fear is activated, it is very difficult to turn off." Al Gore, The Politics of Fear, 2004. ${ }^{1}$

\section{Introduction}

Economists are interested not only in actual dynamics, factors, and consequences of unemployment, but in subjective perceptions and expectations of unemployment as well. Fear of unemployment is one such perception and it affects human behavior. Fear of unemployment may decrease wages (Blanchflower, 1991; Aaronson and Sullivan, 1998; Campbell et al., 2007; Blanchflower and Shadforth, 2007), contain consumption (Stephens, 2004; Benito, 2006), negatively affect health (Burgard et al., 2009), suppress subjective wellbeing, and complicate family relations (Burchell, 1994), among other things.

The distribution of unemployment fear across the population is also of high importance. First, workers' subjective perceptions of unemployment (as well as objective data

(c) 2012 Gimpelson and Oshchepkov; licensee Springer. This is an Open Access article distributed under the terms of the Creative Commons Attribution License (http:/creativecommons.org/licenses/by/2.0), which permits unrestricted use, distribution, and reproduction in any medium, provided the original work is properly cited. 
on unemployment rates and durations, firings, job losses, etc.) are traditionally considered as indicators for the efficiency of the existing social and employment protections (e.g., OECD, 1997; Manski and Straub, 2000; Clark and Postel-Vinay, 2009). Second, workers' fear of unemployment can be a measure of likelihood of future unemployment. As we know, expectations are likely to affect future behaviour. Third, politicians often use various fears as a convenient tool for political manipulation. ${ }^{2}$ Widespread fear of unemployment can induce politicians to support more rigid employment protection legislation (EPL). In its turn, more rigid EPL is likely to suppress job creation in the formal sector and to expand informal sector employment. These outcomes feed fears, creating a vicious circle that is hard to disrupt (Clark and Postel-Vinay, 2009). Fourthly, the fear may serve various particularistic interests as well. By heightening fears of unemployment among the population and falsifying inflated forecasts to this end, a Labor Ministry responsible for employment programs and support of the unemployed can get additional funds from the state coffers. Large enterprises can exploit this fear in order to lobby for subsidies from the government and pressure workers for wage concessions. $^{3}$

These results motivate research in factors that may drive these fears. As multiple studies on this issue show, fear of unemployment varies across social and demographic groups (e.g., Manski and Straub, 2000; Elman and O'Rand, 2002). In general, more competitive workers and employees in better-protected jobs tend to express less fear of unemployment. The quality of institutional environment where firms and workers operate matters as well. However, trends in actual unemployment remain the most natural cause of this fearfulness, and many studies confirm this hypothesis. The fear of unemployment moves in line with actual unemployment, and even small changes in unemployment are translated into significant changes in the level of fear (e.g., Schmidt, 1999; Green et al., 2000; Campbell et al., 2007).

This paper considers the case of Russia, where the link between actual unemployment and individual fearfulness can be weak or seriously muted. On the one hand, economic development over the last 20 years was extremely bumpy, with large swings in the GDP growth followed by increases (or decreases, correspondingly) in the unemployment rate. On the other hand, as available survey evidence suggests, workers' subjective perceptions of job instability were highly inertial and showed little reaction to actual trends.

The fear of unemployment among Russian workers and its tentative determinants were explored earlier in Gimpelson et al. (2003) and Linz and Semykina (2008). Findings from these two papers note some anomalies that mark the Russian labor market in comparison to the labor markets in more advanced economies. For example, in Russia this fear is not gender neutral (women are more fearful in this respect than men are) and it increases over age and tenure (in most countries, job tenure tends to reduce fears). As to the relationship between actual labor market conditions and unemployment fear, the authors of both papers conclude that it did not appear early in the transition but became statistically significant later on. However, these papers did not consider the period after 2004, when fears remained high despite rapid economic growth and further unemployment decline.

In this paper, using the Russian Longitudinal Monitoring Survey data, we study the association between actual unemployment and fear of unemployment in the period from 1994 to 2009. This period includes the years of steep transformational recession 
(1994-1998), the phase of recovery and growth (2000-08), and the recent economic crisis (2008-2009). We employ two alternative measures for this fear. The first measure looks at the fear of losing one's current job, while the second deals with the fear of not finding relevant re-employment in case of displacement. Our methodology is based on estimating an ordered probit model, where fearfulness is regressed on actual unemployment rates with controls for individual and job characteristics. Besides the standard regional unemployment rates, we use unemployment rates for local peer groups that are based on estimates from the Russian Labor Force Survey. These indicators are better proxies of labor market-related risks for particular workers and have larger variance.

The key finding of our study is that unemployment-related fearfulness of workers is weakly linked to the actual unemployment rate. These results are robust to exclusion of potentially endogenous variables; they hold for different periods, subsamples and regardless of variation in levels of jobs security. Even if an association exists, the practical impact of unemployment on perceptions is subtle. As simulations show, drastically large fluctuations in unemployment add practically little to intensity of fears. These results allow suggest that the high level and persistence of fear of unemployment in Russia may be caused by non-economic factors.

The next section presents the story of the Russian labor market over the period of 2000-09 and how it is reflected in subjective perceptions. Section 3 explains our research methodology and empirical data. A descriptive analysis of the fear-related variables is provided in Section 4. Sections 5 and 6 discuss findings from the econometric analysis. In the conclusion, we sum up our major findings and outline further research efforts.

\section{Labor market trends and institutional change: could they affect fear of unemployment?}

\subsection{Main trends}

Soon after the financial crisis of 1998, the unemployment rate reached a record high of $14.6 \%$. However, in early 1999 it started to decline rapidly, thus reacting to the economy's return onto a path of growth. The unemployment rate declined during the whole period between 2000 and 2007 and was less than 6\% by mid-2008. The proportion of those who lost their jobs due to lay-offs, dismissals, and bankruptcy among all unemployed persons decreased from $26 \%$ in 2000 to under $19 \%$ in $2008 .{ }^{4}$

Meanwhile, the economic recovery affected all other labor market indicators as well. The employment to population (e/p) ratio increased by $5 \mathrm{pp}$, previously accumulated wage arrears decreased, the incidence of underemployment decreased, and the number of annual hours worked increased. The problem of excess employment, which was typical for many firms in the 1990s, was replaced by its opposite - the widely publicized "threat of total labor shortage". ${ }^{5}$ Hiring rates stayed high and were positively correlated with vacancy rates. But the most impressive labor market development was presented by the real wage growth, which, according to the Russian Statistical Service (Rosstat), was an annual 12-15\% over the whole period. As a result, by 2008 the Russian labor market looked completely differently than in 1999 or 2000. These developments should have weakened a potential fear of unemployment. 
Of course, a more detailed look could paint a less optimistic picture. The number of those employed in the corporate sector (and thus formally exposed to the EPL protection) decreased from 52 million workers to about 48 million or by 7-8 pp. The proportion of workers in volatile jobs - temporary or casual - increased, as did the informal sector employment. In other words, the proportion of workers in various "bad" jobs rose continuously (Lehmann et al., 2011). Many workers had their own first-hand experience of volatile employment and this could implicitly feed feelings of insecurity and anxiety. However, persistently high hiring rates meant that losing an insecure job was quite easily compensated by finding a new one similar to the former position.

The economic crisis of 2008-09 strongly affected the labor market, but its measurable toll emerged with a lag. Despite multiple layoff announcements, there was little downsizing in 2008. The unemployment rate in q4 2008 was a modest 7\%, but this was 1.3 pp higher than 1 year earlier. In 2009, the unemployment rate reached $8.5 \%$ and all other labor market indicators began to change as well: rapid real wage growth turned to slightly negative growth, wage arrears (though quite modest) reappeared, and underemployment was on the rise again (Gimpelson and Kapeliushnikov, 2011). The expectation of mass dismissals in large firms became a new focus of media attention and a factor of growing public concern. Nevertheless, this grim period was rather short and all indicators soon (in 2010) improved, signaling that the major threat had passed by.

Summing up, most of the actual labor market trends over this period should have cushioned fears, though some developments could have an ambiguous impact on subjective perceptions. Objective causes for more fearfulness emerged by the end of the period under study. This balance could, of course, vary across social and demographic groups of employees.

\subsection{Institutional changes}

Major labor market institutions were largely shaped in the early 1990s and with some modifications survived throughout the 2000s. The Russian authorities have never considered this policy area an explicit priority. Their implicit goal in the institution building was to prevent mass downsizing of the labor force which was considered a threat to political stability. In the 1990s, both the minimum wage and the UB replacement ratio remained low, and the variable part of the labor compensation became tied to the economic performance of firms. This framework provided wages with high flexibility and accommodated strong external shocks through price adjustment (OECD, 2011; Gimpelson and Kapeliushnikov, 2011). Meanwhile, the EPL, materialized in the slightly adjusted old Soviet Labor Code, remained quite rigid though weakly enforced. ${ }^{6}$ High wage dispersion fostered quitting and very buoyant labor turnover in general. Rare lay-offs were of no surprise in such a setting.

Institutional changes in the Russian labor market that took place in the 2000s could hardly strengthen any feelings of insecurity. The new Labor Code enacted in 2001 did not affect the core of major protective regulations, while the government tried to improve enforcement of labor contracts and labor regulations. These changes, if gauged formally, were aimed at providing more job protection to workers and should cushion potential fears.

Quantitative indicators reflecting the actual functioning of institutions may draw a different picture. The actual EPL coverage of workers tended to shrink (with the decline in the proportion of workers in firms where EPL was potentially enforceable) from 
two thirds to half of all employed in the economy. ${ }^{7}$ This indicated the growth of the fraction of unprotected workers. Doubling the minimum wage annually in 2006-09 accelerated the wage growth in the lower part of the wage distribution, thus increasing the economic value of low paid corporate jobs. Multiple wage increases in the public sector during the second half of the 2000s worked in the same way. The increase in wages and stronger wage compression in the left tail of the distribution could simultaneously eject low productive workers out of jobs. Since the rapid average wage growth was associated with a decrease in the UB replacement ratio ${ }^{8,}$ the total costs of unemployment to workers tended to rise.

This part of the story suggests that institutional changes were not clear-cut from the point of their impact on subjective insecurity.

\subsection{Level and dynamics of unemployment fears}

Now we turn to the fears themselves. Figure 1 presents the evolution of the two RLMS-based indicators for subjective perceptions of insecurity in the Russian labor market during 1994-2009. Both indicators are scaled in percents to their levels in 1994. The first reflects the proportion of those who fear losing their job (the proportion of workers who said they were very concerned or concerned with potential job loss) and the second one shows the proportion of those who fear not finding a new job of comparable quality (the proportion of workers who said they were absolutely unsure or somewhat unsure they would find a job of comparable quality if they were fired). ${ }^{9}$

As Figure 1 suggests, throughout the 2000s the subjective insecurity in Russia was quite inertial. It stayed high compared to other countries (Figure 2 and Figure 3). The proportion of those who feared losing their jobs was persistently above 50\% (and the proportion of those who feared not finding a new one exceeded $40 \%$ except 2007). To compare: in the 1990s, in the USA and the UK, the proportion of workers who feared losing their jobs was under 10\% (e.g., Aaronson and Sullivan, 1998; Campbell et al. 2007). This fits the general cross-country picture showing that the level of fear among Russian workers is much stronger than in developed countries under the given rate of

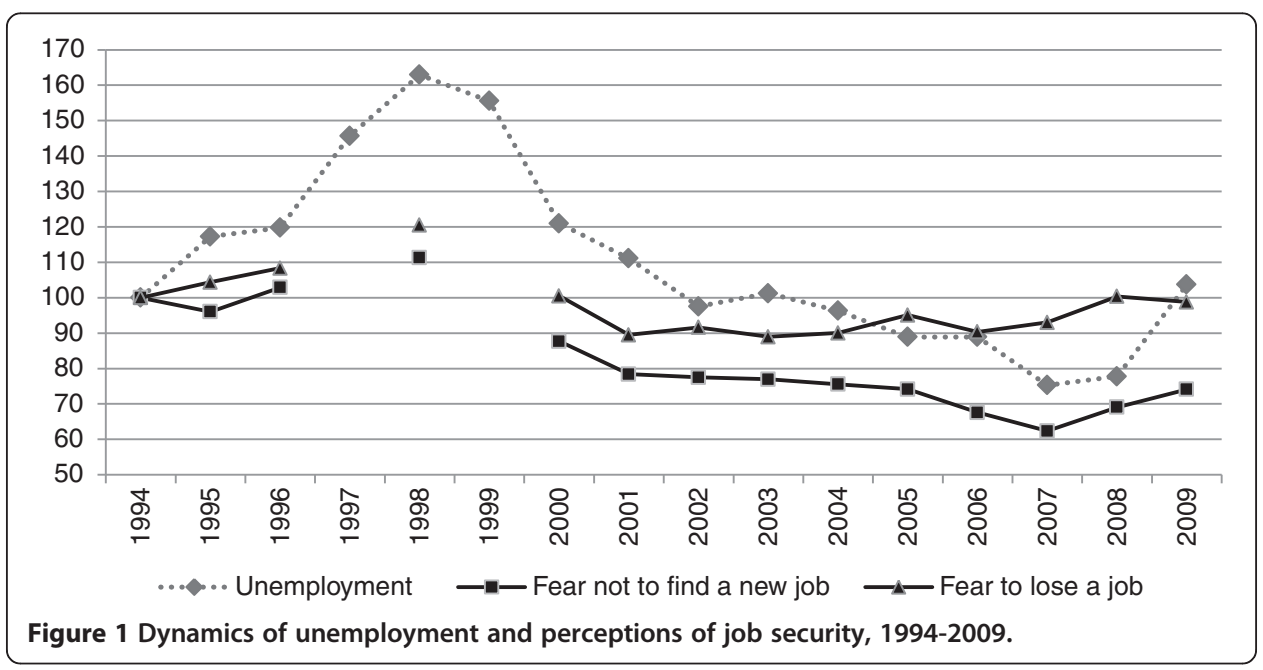




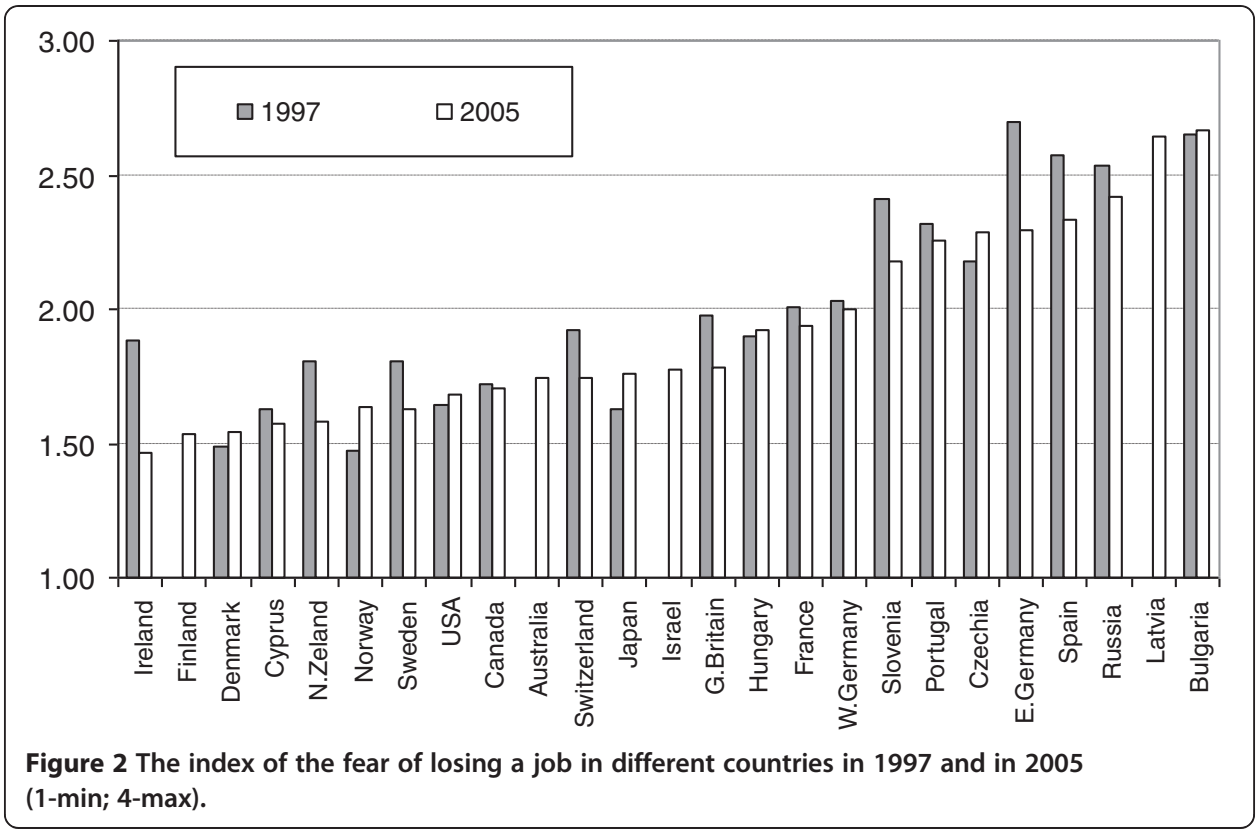

unemployment (Gimpelson and Monusova, 2009). Moreover, the rigid EPL in Russia clearly contrasts to the much more liberal regulations in the US or the UK. ${ }^{10}$ Russians' fear of losing their jobs is similar to workers in Latin America (Figure 3) where the rigid EPL only covers the relatively small formal sector and modern unemployment protection is almost non-existent (Graham, 2002).

The positive association between the stringency of job protection and the level of fear that we observe may seem counterintuitive. However, strong fear of unemployment (regardless of its origin) can boost demand for stricter EPL. Stricter EPL, if delivered by politicians, in turn suppresses job creation and increases pressure on workers in times of crisis. The latter may have a further impact on subjective insecurity thus closing the circle (Wasmer, 2006). ${ }^{11}$

Another interesting observation is that the subjective perceptions of Russian workers seem to be inertial and only somewhat sensitive to the actual state of the labor market. The dotted line in Figure 1 reflects the actual unemployment dynamics. Despite the fact that the unemployment rate was halved between 1998 and 2007, the proportion of workers fearful of losing their job only declined from $69 \%$ to $53 \%$. The proportion of those who feared not finding a job in this period declined more, but it stayed steadily above $40 \%$ except in 2007. The period after 2004 when the indicators of fear continued to stay high despite a rapid decline in actual unemployment was not considered in the previous studies (Linz and Semykina, 2008; Gimpelson et al., 2003). A slight upward turn in both indicators emerged in late 2008, when the economy started to slide into the new crisis. In 2009, the unemployment rate increased by 2 pp, causing little response in indicators of fear.

Stability in the average levels of unemployment fear reflects strong inertia in individual perceptions. About $40 \%$ of workers did not move along fear scales, even during dramatic macroeconomic events and labor market changes associated with the crises of 1998 and 2008-09. Around 70\% of workers who feared losing their job in the year t still reported this fear in the year $t+1$. Those who reported very strong fear did not change 


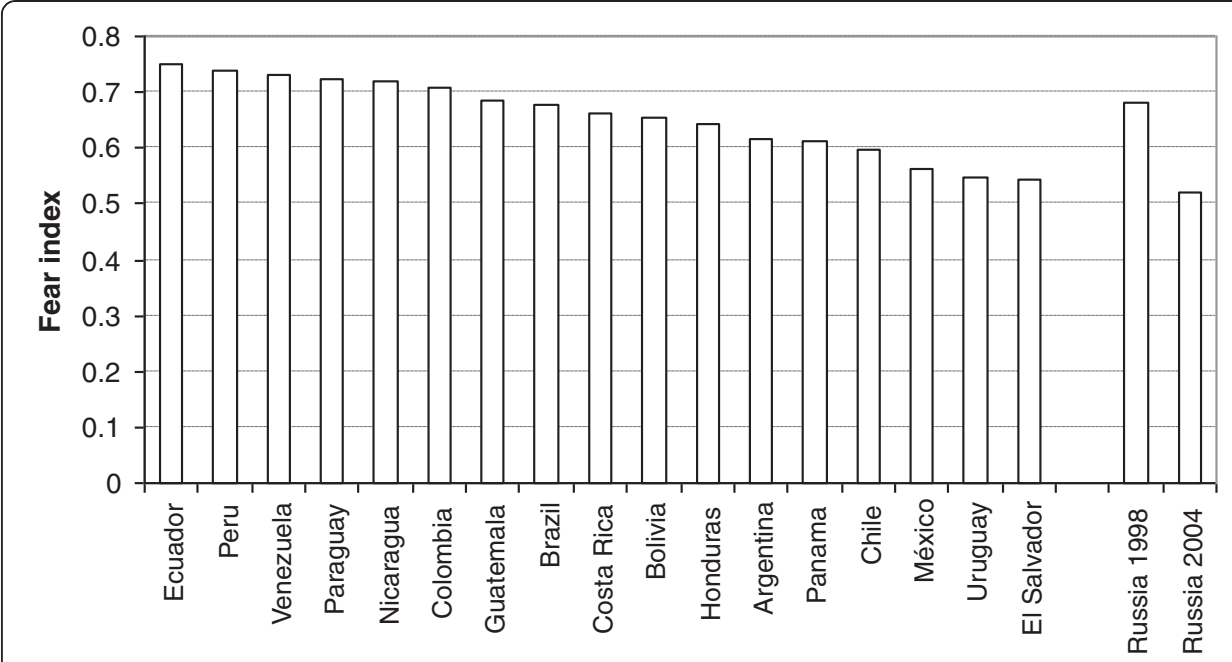

Figure 3 The index of the fear of unemployment in Russia and Latin American countries.

their perceptions, even in the period of robust economic growth and of rapid decline in unemployment. Workers' perceptions concerning finding a new job after being fired were even more stable over time. This provides additional evidence that subjective perception of job security seems to be inertial and somewhat sheltered from external objective circumstances.

The discussion presented above brings us to our main hypothesis that subjective perceptions of unemployment in Russia are not caused by actual labor market developments. In the following paragraphs we will test this proposition and discuss potential implications.

\section{Methodology and data}

Our study uses microdata from the Russian Longitudinal Monitoring Survey (RLMS). The RLMS is the only representative household survey in Russia containing a wide set of questions on labor activity, including questions about unemployment-related fears. We exploit the pooled data set containing all waves from 1994 to 2009.

The empirical strategy is based on estimation of the following equation:

$$
\text { Fear }_{i t}=\beta_{0}+\beta_{1} U_{j t}+\beta_{2} D_{u}+\beta_{3} I C_{i t}+\beta_{4} J C_{i t}+\tau_{t}+\varepsilon_{i t}
$$

The LHS variable $\left(\right.$ Fear $\left._{i t}\right)$ can be measured using two different survey questions (see below). We are interested in a causal effect between this variable and the actual unemployment rate $(\mathrm{U})$. Index $i$ stands for individual, $j$ for region (or specific peer group), for which unemployment is measured, and $t$ for year. We control for individual characteristics of workers (IC), job characteristics (JC), and individual unemployment experience $\left(D_{\mathrm{u}}\right)$. Fixed time effect $\tau$ captures the effect of time-related factors affecting all workers simultaneously. ${ }^{12}$

The level of fear in the RLMS is measured in the following ways. The first question is: «To what extent are you concerned that you may lose your job?» (FEAR_1).

The second question is: «Imagine an unpleasant outcome: the firm or organization you work for is going to be closed and all workers will be fired. To what extent are sure you will able to find a new job which is not worse that the current one?» (FEAR_2). 
The two questions are complementary. The first question is supposed to measure how respondents evaluate the likelihood of losing their current job, while the second measures the likelihood of finding new employment of comparable quality and related financial and emotional costs. Each question allows for five alternative answers ordered from 1 (the lowest level of fear) to 5 (the highest level). ${ }^{13}$ We estimate the model (1) using the ordered probit technique taking into account clustering of errors across individuals. We do all estimations separately for both questions since they differ in nuance. As shown above, in the 1990s, the indexes based on these questions moved almost identically. In the second half of the 2000s, they started to diverge and for older workers, this was especially the case.

Both questions are asked in all RLMS waves and have already been used to study subjective insecurity in Russia. ${ }^{14}$ The wording of the questions is similar to those used in other countries. The difference is that such questions often have references to a particular period of time, e.g. one year. (See, e.g., Dominitz and Manski, 1996; Fullerton and Wallace, 2007; Schmidt, 1999; Manski and Straub 2000; Clark and Postel-Vinay, 2009).

For controlling actual labor market situation $\left(U_{j t}\right)$, we alternatively exploit three different variables. The most straightforward approach is to use standard (the ILO type) unemployment rates calculated for each region included in the survey sample. They are widely used in the literature, including two mentioned papers on Russia (Gimpelson et al., 2003; Linz and Semykina, 2008). However, such regional variables have a number of obvious disadvantages. They are too aggregated and therefore may poorly reflect actual labor market related risks for different social and demographic groups living in large and heterogeneous regions. One could expect that the individual fears we are interested in may reflect risks existing for individuals with characteristics similar to our respondents. For example, a 40-year-old man with higher education residing in Voronezh city would consider the labor market situation as it emerges in this city for individuals with observable characteristics similar to his. This discrepancy may result in measurement error for our key regressor leading to the attenuation bias. ${ }^{15}$

In order to overcome the shortcomings of aggregated regional unemployment rates, we calculate group-specific unemployment and non-employment rates. For doing this using LFS micro-data, we form multiple groups as simultaneous breakdowns by region"urban/rural"gender"education variables. Altogether we get 496 specific groups. For each group and for each year (in the RLMS survey), we calculated unemployment rate (as \% of unemployed in economically active population in the group) and nonemployment rate (as \% of non-employed in the total population in the group). ${ }^{16} \mathrm{We}$ can do this because the LFS sample is much larger than the RLMS sample. Then we impute these values to every respondent in our RLMS sample and use these groupspecific labor market indicators in our base specifications. They have much larger variation than standard regional unemployment rates have and are less subject to the measurement error problem.

We measure former unemployment experience using two dummy variables. The first equals 1 if our respondent was unemployed at least once over the survey period, and to 0 otherwise. The second equals 1 if a respondent was unemployed in the previous wave and to 0 otherwise. ${ }^{17}$

We control for individual characteristics (gender, age and age squared, education, marital status, occupation, getting a pension, tenure and tenure squared, having a 
second job, and type of residence) and for job characteristics (firm size, having subordinates, having wage arrears). The macro-region where our respondents reside is also controlled.

If the first group of variables (individual characteristics) reflects the bargaining power of individuals on the labor market, the second one (job characteristics) measures risks associated with the quality of these jobs. One could assume that fear of job loss tends to be lower for employees working in the public sector than in the private sector, lower for workers at large enterprises than at small ones, and lower for those working formally than those informally. ${ }^{18}$

The extent to what workers fear losing their jobs can be affected not just by the likelihood of losing their job, but also by the costs associated with the loss for a worker. For example, these costs may be lower if a worker has alternative income sources (a second job or a pension).

The descriptive statistics for all repressors used in the paper is presented in Table 1. We restrict the sample to individuals who were between the ages of 15 and 72 in the year of observation. Two sub-periods considered in the paper (1994-1998 and 20002008) reveal some important differences. In the second sub-period, the proportion of employed by the state kept declining, but the unemployment rate and the incidence of wage arrears went down quickly.

\section{Descriptive analysis of fear}

Table 2 presents descriptive statistics for FEAR_1 and FEAR_2 across major groups of workers.

Table 1 Descriptive statistics

\begin{tabular}{lcccccc}
\hline & \multicolumn{3}{c}{ 1994-1998 } & \multicolumn{3}{c}{ 2000-2009 } \\
\hline Variable & Mean & Min & Max & Mean & Min & Max \\
\hline Female (1-yes; 0-no) & 0.49 & 0 & 1 & 0.51 & 0 & 1 \\
\hline Age (years) & 39.16 & 15 & 72 & 38.85 & 15 & 72 \\
\hline Receiving pension (1-yes; 0-no) & 0.12 & 0 & 1 & 0.13 & 0 & 1 \\
\hline Education level (1 - below secondary; & 3.00 & 1 & 4 & 3.10 & 1 & 4 \\
2-secondary; 3 - vocational; 4 -tertiary) & & & & & & \\
\hline Tenure (years) & 7.94 & 0 & 56 & 7.09 & 0 & 58 \\
\hline Married (1-yes; 0-no) & 0.75 & 0 & 1 & 0.71 & 0 & 1 \\
\hline State ownership (1-yes; 0-no) & 0.67 & 0 & 1 & 0.47 & 0 & 1 \\
\hline Having subordinates (1-yes; 0-no) & 0.23 & 0 & 1 & 0.22 & 0 & 1 \\
\hline Having second job (1-yes; 0-no) & 0.05 & 0 & 1 & 0.05 & 0 & 1 \\
\hline Having wage arrears (1-yes; 0-no) & 0.51 & 0 & 1 & 0.14 & 0 & 1 \\
\hline Living in a rural settlement (1-yes, 0- no) & 0.28 & 0 & 1 & 0.29 & 0 & 1 \\
\hline Living in Moscow or St. Petersburg (1-yes; 0-no) & 0.10 & 0 & 1 & 0.13 & 0 & 1 \\
\hline Unemployment experience (1-yes, 0-no) & 0.05 & 0 & 1 & 0.13 & 0 & 1 \\
\hline Unemployed in previous year (1-yes, 0-no) & 0.03 & 0 & 1 & 0.03 & 0 & 1 \\
\hline The level of regional unemployment (\%) & 10.10 & 4.8 & 23.9 & 7.61 & 0.8 & 25.7 \\
\hline The level of specific unemployment (\%) & 11.94 & 0.88 & 54.12 & 10.96 & 0.11 & 60.02 \\
\hline The level of specific non-employment (\%) & 49.5 & 2.27 & 92.84 & 55.42 & 1.55 & 93.89 \\
\hline
\end{tabular}




\subsection{Individual characteristics}

Fear of unemployment varies by gender and age groups. FEAR_1 is inversely U-shaped over age. The strongest fear was in the age group of 46-59 years old. Here, $63 \%$ of workers in the first sub-period and 55\% in the second one feared losing their jobs. For workers over 59 years old, these proportions were smaller by 13 and $10 \mathrm{pp}$. This corresponds with the fact that unemployment-related risks seem to be the highest for the pre-pension age but then with age they go down due to the appearance of alternative (pension) income. The proportion of those fearful of job loss in the 30-45 age group decreased by 12 pp between the two sub-periods, and this decrease was largest among all age groups.

On the contrary, fear of not finding a job (FEAR_2) changes monotonically with age and reaches the maximum in the pension age group. The decrease in this fear over time (between the sub-periods) was largest (by $20 \mathrm{pp}$ ) for the youngest age group and smallest (by $8 \mathrm{pp}$ ) for the oldest.

Women compared to men are more afraid of losing job but the gender gap is lower in the second sub-period. The same is true in case of fears associated with job search.

Increased educational levels weaken fears and reduce between-group differences. In the 1990s, higher education was associated with significantly lower fears, but this difference largely evaporated in the 2000. Those respondents who have families tend to have stronger fear than those without, though the difference is of low significance.

Rural residents report greater fear than urban residents: among the latter, residents of Moscow and Saint Petersburg are least likely to report unemployment fear. These differences in perceptions may reflect differences in access to jobs as well as differences in human capital endowments.

Having a second job that can indirectly mirror labor market competiveness (through alternative or complementary professional skills) expectedly weakens fears. In case of job loss, the availability of alternative income decreases the costs of temporary joblessness and of the job search. On the contrary, wage arrears, if they exist, reflect both a worker's low market power and job volatility.

\subsection{Job characteristics}

One could expect that occupying a better-protected job would reduce anxiety about its potential loss. However, the data do not suggest that better protected jobs (located in the public sector, in large firms, and with fully formal labor contracts) are associated with weaker fears.

State sector workers are more prone to stronger fears than workers in the private sector are. These differences are even more pronounced in the case of job search (var. FEAR_2). As an employer, the state is expected to provide more secure jobs, and workers are expected to feel this security. Even more counterintuitive is the evidence that informal workers (those without a formal contract) seem to have a weaker fear of job loss. In the 2000s, in this group both variables of fear had the lowest values among all groups that are presented in Table 2 . The level of fear shows little variation by firm size: workers at large firms perceive job insecurity as much as workers at small firms do.

Having subordinates correlates with lower anxiety. On the one hand, this factor reflects a worker's hierarchical status; on the other, more energetic and able workers 
Table 2 Percentages of workers who fear of losing their jobs and not finding a new one (percentage of workers choosing values "4" or " 5 " when answering the fear questions), by subgroups of workers, RLMS, 1994-1998 and 2000-2009

\begin{tabular}{|c|c|c|c|c|c|}
\hline & & \multicolumn{2}{|c|}{ Fear of losing } & \multicolumn{2}{|c|}{ Fear of not finding } \\
\hline & & 1994-1998 & 2000-2009 & 1994-1998 & $2000-2009$ \\
\hline \multirow[t]{4}{*}{ Age } & $15-29$ & 55.04 & 47.47 & 51.4 & 31.1 \\
\hline & $30-45$ & 64.8 & 55.15 & 63.15 & 42.05 \\
\hline & $46-59$ & 65.12 & 58.46 & 70.95 & 59.13 \\
\hline & $60-72$ & 49.69 & 46.86 & 73.66 & 66.49 \\
\hline \multirow[t]{2}{*}{ Gender } & Female & 58.06 & 55.05 & 70.93 & 49.84 \\
\hline & Male & 65.28 & 51.72 & 54.09 & 39.29 \\
\hline \multirow[t]{4}{*}{ Education level } & $\begin{array}{l}\text { Lower than } \\
\text { secondary }\end{array}$ & 64.93 & 54.28 & 71.09 & 49.68 \\
\hline & Secondary & 63.39 & 53.84 & 64.86 & 46.12 \\
\hline & Vocational & 64.57 & 54.54 & 63.31 & 42.16 \\
\hline & Tertiary & 58.76 & 52.72 & 59.52 & 45.18 \\
\hline \multirow[t]{2}{*}{ Married } & Yes & 62.06 & 54.11 & 62.97 & 45.61 \\
\hline & No & 60.65 & 51.88 & 62.01 & 43.21 \\
\hline \multirow[t]{2}{*}{ State ownership } & Yes & 62.08 & 53.67 & 64.6 & 48.82 \\
\hline & No & 60.35 & 54.04 & 58.11 & 41.51 \\
\hline \multirow[t]{5}{*}{ Firm size } & $<51$ employees & 61.48 & 52.57 & 62.78 & 43.84 \\
\hline & $51-100$ & 60.26 & 52.72 & 61.27 & 42.97 \\
\hline & $101-200$ & 62.69 & 52.57 & 64.44 & 45.67 \\
\hline & $201-1000$ & 60.68 & 56.07 & 64.08 & 48.32 \\
\hline & >1000 employees & 62.54 & 54.97 & 63.55 & 44.53 \\
\hline \multirow[t]{2}{*}{ Informal employment } & Yes & 55.81 & 44.88 & 54.12 & 27.95 \\
\hline & No & 69.29 & 54.73 & 68.48 & 45.7 \\
\hline \multirow[t]{2}{*}{ Having subordinates } & Yes & 57.04 & 50.65 & 56.19 & 42.03 \\
\hline & No & 63.13 & 54.28 & 64.75 & 45.78 \\
\hline \multirow[t]{2}{*}{ Having second job } & Yes & 44.91 & 41.87 & 41.64 & 30.4 \\
\hline & No & 62.53 & 54.06 & 63.78 & 45.7 \\
\hline \multirow[t]{2}{*}{ Having wage arrears } & Yes & 65.23 & 54.75 & 67.68 & 51.28 \\
\hline & No & 58.61 & 53.79 & 57.68 & 43.92 \\
\hline \multirow[t]{2}{*}{ Receiving pension } & Yes & 56.03 & 51.65 & 73.8 & 62.11 \\
\hline & No & 62.51 & 53.77 & 61.27 & 42.32 \\
\hline \multirow[t]{2}{*}{ Rural settlement } & Yes & 66.07 & 59.69 & 73.34 & 59.09 \\
\hline & No & 60.09 & 51.2 & 58.7 & 39.81 \\
\hline \multirow[t]{2}{*}{ Moscow or St. Petersburg } & Yes & 50.31 & 41.11 & 47.3 & 35.32 \\
\hline & No & 62.97 & 55.33 & 64.44 & 46.47 \\
\hline \multirow[t]{2}{*}{ Unemployment experience } & Yes & 66.99 & 53.62 & 65.30 & 45.47 \\
\hline & No & .63 .63 & 52.92 & 63.25 & 42.67 \\
\hline \multirow[t]{2}{*}{ Unemployed in previous year } & Yes & 69.10. & 52.65 & 64.14. & 41.48 \\
\hline & No & .63 .62 & .53 .56 & 63.31 & 45.22 \\
\hline \multirow{4}{*}{$\begin{array}{l}\text { The level of regional } \\
\text { unemployment }\end{array}$} & $\mathrm{u}<\mathrm{p} 25^{*}$ & 58.71 & 47.67 & 58.44 & 38.83 \\
\hline & $\mathrm{p} 25<\mathrm{u}<\mathrm{p} 50$ & 58.71 & 55.54 & 60.51 & 45.2 \\
\hline & $\mathrm{p} 50<\mathrm{u}<\mathrm{p} 75$ & 61.28 & 55.64 & 63.75 & 50.12 \\
\hline & $\mathrm{p} 75<\mathrm{u}$ & 69.22 & 56.71 & 68.86 & 47.5 \\
\hline \multirow{2}{*}{$\begin{array}{l}\text { The level of specific } \\
\text { unemployment }\end{array}$} & su<p25 & 64.24 & 50.38 & 68.12 & 42.42 \\
\hline & p25<su<p50 & 60.28 & 52.66 & 62.28 & 44.24 \\
\hline
\end{tabular}


Table 2 Percentages of workers who fear of losing their jobs and not finding a new one (percentage of workers choosing values "4" or " 5 " when answering the fear questions), by subgroups of workers, RLMS, 1994-1998 and 2000-2009 (Continued)

\begin{tabular}{lllccc}
\hline & $\mathrm{p} 50<\mathrm{su}<\mathrm{p} 75$ & 59.07 & 55.09 & 60.49 & 46.14 \\
\cline { 2 - 6 } & su>p75 & 63.54 & 54.99 & 61.17 & 46.37 \\
\hline $\begin{array}{l}\text { The level of specific } \\
\text { non-employment }\end{array}$ & sne<p25 & 61.76 & 52.83 & 63 & 44.93 \\
\cline { 2 - 6 } & $\mathrm{p} 25<\mathrm{sne}<\mathrm{p} 50$ & 64.16 & 54.99 & 64.05 & 46.21 \\
\cline { 2 - 6 } & $\mathrm{p} 50<\mathrm{sne}<\mathrm{p} 75$ & 59.47 & 53.25 & 58.15 & 42.95 \\
\cline { 2 - 6 } & sne>p75 & 62.23 & 53.2 & 65.93 & 46.06 \\
\hline
\end{tabular}

${ }^{*} \mathrm{p} 25, \mathrm{p} 50, \mathrm{p} 75$ are values for the $25 \%, 50 \%$, and $75 \%$ percentiles of the regional unemployment distribution, respectively.

are likely to be non-randomly selected to such positions. Unconditional averages suggest that less competitive and more risk-averse workers are more likely to end up in better-protected jobs. ${ }^{19}$ Individuals with a particular set of observable and nonobservable characteristics tend to be concentrated in particular types of jobs. Driven by their preferences, workers may accept lower wages, thus providing arguments for the theory of compensating differentials. In our case, fear of job loss can motivate workers to minimize labor market risks and therefore to encourage them to search for more secure jobs (in the public sector, large firms, and with formal contracts). This kind of sorting reduces the aggregate fear level, which could otherwise be higher (if workers were randomly assigned accross protected and unprotected positions). As our previous research shows, public sector jobs and better protected jobs in Russia are associated with lower earnings. ${ }^{20}$

\subsection{Labor market characteristics}

Since unemployment and non-employment are continuous variables, we divide their distributions into quartiles (p25, p50, p75). These quartiles are associated with different situations that can be called low, medium, and high unemployment (Table 3). Though rising unemployment and non-employment tend to drive fears up, the associated increase in fears is not proportional to unemployment growth. For example, shifts from the low value of group-specific unemployment to the high value in the first sub-period was accompanied by weakening fears (potentially due to some social learning) and by strengthening fears by $5 \mathrm{pp}$ in the second sub-period. Unconditional effects of groupspecific unemployment rates do not emerge as strong either.

\section{Determinants of fear}

So far we have presented unconditional averages for fears by social and demographic groups of workers. In this paragraph we present econometric estimates of effects of unemployment conditional on other factors. We estimate Eq (1) separately for FEAR_1 and FEAR_2 and for two sub-periods, of which one is for the deep economic decline (1994-1998) while the other is for remarkable growth (2000-2008). For each of the two dependent variables we use three specifications, differing in the way the local labor market situation is described. This description is presented consequently by regional unemployment rates, group-specific unemployment, and non-employment. 
Table 3 Percentiles of the distributions of regional unemployment, specific unemployment and non-employment

\begin{tabular}{lcc}
\hline Regional unemployment (RU) & $\mathbf{1 9 9 4 - 1 9 9 8}$ & $\mathbf{2 0 0 0 - 2 0 0 9}$ \\
\hline $\mathrm{p} 25$ & 7.9 & 5.6 \\
\hline $\mathrm{p} 50$ & 9.6 & 8.0 \\
\hline $\mathrm{p} 75$ & 11.5 & $\mathbf{9}$ \\
\hline Specific unemployment (SU) & $1994-1998$ & $\mathbf{2 0 0 0 - 2 0 0 9}$ \\
\hline $\mathrm{p} 25$ & 6.6 & 4.4 \\
\hline $\mathrm{p} 50$ & 9.9 & 7.9 \\
\hline p75 & 14.1 & 13.4 \\
\hline Specific non-employment (SNE) & $1994-1998$ & $2000-2009$ \\
\hline p25 & 24.9 & 26.8 \\
\hline p50 & 36.2 & 42.0 \\
\hline p75 & 68.4 & 75.4 \\
\hline *p25, p50, p75 are values for the 25\%, 50\%, and 75\% percentiles of the regional unemployment distribution, respectively.
\end{tabular}

\subsection{Fear of job loss}

Table 4 presents estimations of the Eq1 with FEAR_1 as the dependent variable. We estimate it for the both sub-periods pooling the data within each sub-period. ${ }^{21}$ There is a strong gender gap in the first sub-period: women seemed to have much stronger fear than men did. In the second sub-period, the gap tended to shrink but remained statistically significant. The inverse U-type relationship revealed by the descriptive analysis is confirmed for the both sub-periods. While in 1994-98 tertiary education reduced job loss related fears, in the 2000s this factor lost its significance, probably due to a large increase in the supply of skilled labor and growing over-education. Having a pension as an alternative income weakened the fear as expected. The same was true for workers who were married. The positive association with tenure (this fact is also mentioned by Linz and Semykina 2008) goes against what is usually seen in other countries, but corresponds with other studies on Russia. This can be explained by the fact that small investments in firm-specific capital (which is characteristic for Russia) and limited employment opportunities undermine worker's bargaining power at the current job. In the second sub-period, this effect became even stronger.

In 1994-98, employment in state-owned firms was not associated with fear of job loss, but the expected negative relationship emerged later. During the later period, the proportion of state-owned sector employment reduced, while the EPL enforcement in this sector became stronger. Workers more predisposed to stronger anxiety can selfselect the public sector, bringing some endogeneity into the ownership variable. If this were not true, the negative relationship could be even stronger.

Workers employed by large firms tend to fear unemployment more than those employed by small or medium-sized firms. This result holds when we exclude the ownership dummy variable. Again, one could expect to see the contrary, since jobs at large firms are usually better protected. However, they tend to pay higher wages making job loss more painful. In addition, large firms in Russia that are traditionally known for labor hoarding downsized more quickly, thus putting more psychological pressure on their workers. Here again we may see a non-random selection of low-competitive workers with stronger fears of job loss (and therefore a preference for more job security) to larger firms. 
Table 4 Factors influencing the fear of losing a job, RLMS, 1994-2009, oprobit

\begin{tabular}{|c|c|c|c|c|c|c|}
\hline \multirow{2}{*}{$\begin{array}{l}\text { Dependent variable: fear of } \\
\text { losing a job (1-min., 5-max) }\end{array}$} & \multicolumn{3}{|c|}{ 1994-1998 } & \multicolumn{3}{|c|}{$2000-2009$} \\
\hline & RU & SU & SNE & RU & SU & SNE \\
\hline \multirow[t]{2}{*}{ Female } & $-0.291^{* * *}$ & $-0.295^{* * *}$ & $-0.320^{* * *}$ & $0.155^{* * *}$ & $0.154^{* * *}$ & $0.100^{* * *}$ \\
\hline & $(0.032)$ & $(0.033)$ & $(0.070)$ & $(0.025)$ & $(0.026)$ & $(0.031)$ \\
\hline \multirow[t]{2}{*}{ Age (years) } & $0.072^{* * *}$ & $0.069^{* * *}$ & $0.072^{* * *}$ & $0.048^{* * *}$ & $0.047^{* * *}$ & $0.048^{* * *}$ \\
\hline & $(0.009)$ & $(0.009)$ & $(0.009)$ & $(0.006)$ & $(0.006)$ & $(0.006)$ \\
\hline \multirow[t]{2}{*}{ Age squared } & $-0.001^{* * *}$ & $-0.001^{* * *}$ & $-0.001^{* * *}$ & $-0.001^{* * *}$ & $-0.001^{* * *}$ & $-0.001^{* * *}$ \\
\hline & $(0.000)$ & $(0.000)$ & $(0.000)$ & $(0.000)$ & $(0.000)$ & $(0.000)$ \\
\hline \multirow[t]{2}{*}{ Receiving pension } & $-0.107^{* *}$ & $-0.098^{*}$ & $-0.108^{* *}$ & $-0.089^{* * *}$ & $-0.092^{* * *}$ & $-0.086^{* *}$ \\
\hline & $(0.053)$ & $(0.054)$ & $(0.053)$ & $(0.033)$ & $(0.034)$ & $(0.033)$ \\
\hline \multirow{2}{*}{$\begin{array}{l}\text { Education level: secondary } \\
\text { (reference category: } \\
\text { below secondary) } \\
\end{array}$} & $-0.101^{* *}$ & -0.064 & $-0.100^{* *}$ & -0.041 & -0.040 & -0.043 \\
\hline & $(0.048)$ & $(0.048)$ & $(0.048)$ & $(0.030)$ & $(0.031)$ & $\begin{array}{l}(0.030) \\
\end{array}$ \\
\hline \multirow[t]{2}{*}{ Vocational } & 0.007 & 0.057 & 0.033 & -0.028 & -0.036 & $-0.150^{* * *}$ \\
\hline & $(0.041)$ & $(0.045)$ & $(0.061)$ & $(0.029)$ & $(0.030)$ & $(0.047)$ \\
\hline \multirow[t]{2}{*}{ Tertiary } & $-0.116^{* *}$ & -0.063 & -0.023 & -0.043 & $-0.068^{*}$ & $-0.329^{* * *}$ \\
\hline & $(0.046)$ & $(0.052)$ & $(0.197)$ & $(0.035)$ & $(0.041)$ & $(0.110)$ \\
\hline \multirow[t]{2}{*}{ Tenure (years) } & $0.006^{* *}$ & $0.005^{*}$ & $0.006^{* *}$ & $0.009^{* * *}$ & $0.010^{* * *}$ & $0.010^{* * *}$ \\
\hline & $(0.003)$ & $(0.003)$ & $(0.003)$ & $(0.003)$ & $(0.003)$ & $(0.003)$ \\
\hline \multirow[t]{2}{*}{ Tenure squared } & $-0.000^{*}$ & -0.000 & $-0.000^{*}$ & $-0.000^{*}$ & $-0.000^{* *}$ & $-0.000^{* *}$ \\
\hline & $(0.000)$ & $(0.000)$ & $(0.000)$ & $(0.000)$ & $(0.000)$ & $(0.000)$ \\
\hline \multirow[t]{2}{*}{ Married } & -0.051 & -0.051 & -0.051 & $-0.031^{*}$ & -0.026 & $-0.030^{*}$ \\
\hline & $(0.044)$ & $(0.045)$ & $(0.044)$ & $(0.018)$ & $(0.019)$ & $(0.018)$ \\
\hline \multirow{2}{*}{$\begin{array}{l}\text { Firm size: < } 50 \text { employees } \\
\text { (reference category: } \\
>1000 \text { employees) }\end{array}$} & -0.070 & -0.068 & $-0.071^{*}$ & -0.017 & -0.019 & -0.017 \\
\hline & $(0.043)$ & $(0.042)$ & $(0.042)$ & $(0.022)$ & $(0.022)$ & $(0.022)$ \\
\hline \multirow[t]{2}{*}{ 51-100 employees } & $-0.114^{* *}$ & $-0.123^{* * *}$ & $-0.115^{* *}$ & 0.007 & -0.002 & 0.005 \\
\hline & $(0.047)$ & $(0.047)$ & $(0.046)$ & $(0.026)$ & $(0.025)$ & $(0.025)$ \\
\hline \multirow[t]{2}{*}{ 101-200 employees } & -0.021 & -0.039 & -0.019 & $0.075^{* * *}$ & $0.070^{* * *}$ & $0.072^{* * *}$ \\
\hline & $(0.056)$ & $(0.057)$ & $(0.055)$ & $(0.024)$ & $(0.023)$ & $(0.024)$ \\
\hline \multirow[t]{2}{*}{ 201-1000 employees } & -0.046 & -0.052 & -0.045 & $0.089^{* * *}$ & $0.080^{* * *}$ & $0.089^{* * *}$ \\
\hline & $(0.039)$ & $(0.038)$ & $(0.039)$ & $(0.023)$ & $(0.023)$ & $(0.023)$ \\
\hline \multirow[t]{2}{*}{ State ownership } & 0.013 & 0.020 & 0.012 & $-0.066^{* *}$ & $-0.063^{* *}$ & $-0.064^{* *}$ \\
\hline & $(0.033)$ & $(0.034)$ & $(0.033)$ & $(0.027)$ & $(0.027)$ & $(0.027)$ \\
\hline \multirow[t]{2}{*}{ Having subordinates } & $-0.079 * * *$ & $-0.070^{* * *}$ & $-0.078^{* * *}$ & $-0.059^{* * *}$ & $-0.060^{* * *}$ & $-0.060^{* * *}$ \\
\hline & $(0.028)$ & $(0.026)$ & $(0.028)$ & $(0.017)$ & $(0.017)$ & $(0.017)$ \\
\hline \multirow[t]{2}{*}{ Second job } & $-0.363^{* * *}$ & $-0.368^{* * *}$ & $-0.363^{* * *}$ & $-0.283^{* * *}$ & $-0.291^{* * *}$ & $-0.284^{* * *}$ \\
\hline & $(0.050)$ & $(0.051)$ & $(0.050)$ & $(0.033)$ & $(0.034)$ & $(0.034)$ \\
\hline \multirow[t]{2}{*}{ Rural } & $0.140^{*}$ & 0.125 & 0.121 & $0.232^{* * *}$ & $0.226^{* * *}$ & $0.251^{* * *}$ \\
\hline & $(0.072)$ & $(0.081)$ & $(0.083)$ & $(0.054)$ & $(0.054)$ & $(0.055)$ \\
\hline \multirow[t]{2}{*}{ Moscow or St. Petersburg } & -0.156 & -0.149 & -0.129 & $-0.181^{*}$ & $-0.235^{* *}$ & $-0.273^{* * *}$ \\
\hline & $(0.096)$ & $(0.092)$ & $(0.083)$ & $(0.107)$ & $(0.093)$ & $(0.089)$ \\
\hline
\end{tabular}


Table 4 Factors influencing the fear of losing a job, RLMS, 1994-2009, oprobit (Continued)

\begin{tabular}{|c|c|c|c|c|c|c|}
\hline Wage arrears & $-0.070^{* *}$ & $-0.071^{* *}$ & $-0.066^{* *}$ & -0.012 & -0.012 & -0.007 \\
\hline & $(0.032)$ & $(0.031)$ & $(0.031)$ & $(0.028)$ & $(0.030)$ & $(0.029)$ \\
\hline \multirow[t]{2}{*}{ Regional unemployment (\%) } & -0.015 & & & 0.017 & & \\
\hline & $(0.022)$ & & & $(0.012)$ & & \\
\hline \multirow[t]{2}{*}{ Specific unemployment (\%) } & & -0.004 & & & 0.002 & \\
\hline & & $(0.005)$ & & & $(0.002)$ & \\
\hline \multirow[t]{2}{*}{ Specific unemployment (\%) } & & & -0.002 & & & $0.005^{* * *}$ \\
\hline & & & $(0.004)$ & & & $(0.002)$ \\
\hline $\mathrm{N}$ & 11451 & 11075 & 11451 & 48807 & 47068 & 48807 \\
\hline
\end{tabular}

Notes: 1) Standard errors robust to heteroscedasticity, autocorrelation and clusterisation are in parentheses;

2) ${ }^{* * *}$ - significance at $1 \%$ level; ** - significance at $5 \%$ level; *- significance at $10 \%$ level; 3 ) Controls: occupations, federal districts and years; 4) Estimates for constants and cut points are available on request: 5) RU is regional unemployment, $\mathrm{SU}$ is specific unemployment, SNE is specific non-employment.

Interestingly, workers with formal labor contracts show stronger fears than those having informal agreements only. This outcome is robust on all available crosssections $(1998,2000,2002-2008)$ and is reproduced if the relevant dummy is added to the complete specification on the 2002-2008 pool. This is even stronger evidence on self-selection than those mentioned earlier. ${ }^{22}$

Fear of job loss is expectedly stronger among rural residents than among urban residents, and in largest cities it is the weakest. This is explained by the simple fact that the fear of job loss weakens as job opportunities expand. Being a supervisor for other workers, as a rule, adds power and reflects a relative value of such worker for a firm. Wage arrears were associated with stronger fears in the first sub-period as an indirect indication of bad financial situation at his/her firm as well as his/her relative value for employer. However, the sharply decreased incidence of wage arrears in the second sub-period made this factor statistically insignificant.

How did local labor markets affect feelings of fear? Do signals sent by actual unemployment to workers strengthen or weaken subjective insecurity? As we show further, these signals if accepted by workers turn out to be of weak influence.

As already noted, we use three different indicators of local labor market conditions: regional unemployment rate (RU), group-specific unemployment rate (SU), and group-specific non-employment rate (SNE). In the first sub-period, coefficients for all of these indicators were negative and of no significance. In the second sub-period, all coefficients become positive, but only the coefficient for group-specific non-employment achieves significance. ${ }^{23}$ Does higher unemployment transpire into stronger perceptions of insecurity? In order to answer this question, getting just statistical significance is not enough and we are interested in practical significance as well.

The associations between fear of unemployment and personal experience of unemployment (given that all other variables are controlled for) are presented in Table 5. We present them in a separate table since inclusion of the variables for personal experience significantly reduces the sample. The association is insignificant regardless of which indicator of previous experience is used. This finding is reproduced in all specifications, including annual cross-sections. Meanwhile, statistical significance for various unemployment variables is not changed (see Section 6). 


\subsection{Fear of not finding a job}

The estimates from Eq. (1) for the alternative variable of fear (fear of not finding a new job or FEAR_2) largely reproduce the results presented above (Table 6), though with some nuances.

Women are more likely than men to fear not finding a new job. The age effect in the second sub-period disappears, and marital status has no effect in the either period. Place of residence matters: urban residents fear job finding difficulties less than rural residents do, and residents of Moscow and Saint Petersburg fear not finding a new job even less. In the first sub-period, tertiary education only affected fear negatively and this effect did not hold when variables for group-specific unemployment or nonemployment were included. In the second sub-period, workers with primary vocational education were least afraid of not finding reemployment, while those without general secondary were most afraid. The latter group differs significantly from all others. Getting a pension or secondary job provide additional «secured» income that decreases job search costs. In the first period, personal exposure to wage arrears was among the determinants of fear, but this effect disappeared in the second sub-period.

Effect of job characteristics of jobs on fear is ambiguous. Workers in small firms fear less and probably are used to more frequent mobility and job change. Working for state owned firms does not matter.

Now let us turn to the labor market indicators. In the first sub-period, they were statistically insignificant, but later they became significant with the expected sign. However, only two of three specifications (with regional unemployment and groupspecific non-employment) remained significant cluster robust with clustering on individuals.

Being unemployed in the past strengthens fears of not finding a new job significantly, other things equal (see Table 7). Those who have already faced reemployment after being unemployed are likely to better understand the associated costs. Using the alternative variable that reflects unemployment status one year before the survey period confirms this association (between the UN experience and FEAR_2).

Table 5 Personal unemployment experience and fear of losing a job, RLMS, 1994-2008, oprobit

\begin{tabular}{|c|c|c|c|c|c|c|}
\hline \multirow{2}{*}{$\begin{array}{l}\text { Dependent variable: fear of } \\
\text { losing a job (1-min., 5-max) }\end{array}$} & \multicolumn{3}{|c|}{ 1994-1998 } & \multicolumn{3}{|c|}{$2000-2008$} \\
\hline & RU & SU & $\overline{\text { SNE }}$ & RU & SU & SNE \\
\hline \multirow[t]{2}{*}{ Regional unemployment (\%) } & -0.010 & & & 0.018 & & \\
\hline & $(0.006)$ & & & $(0.012)$ & & \\
\hline \multirow[t]{2}{*}{ Specific unemployment (\%) } & & -0.003 & & & 0.001 & \\
\hline & & $(0.005)$ & & & $(0.002)$ & \\
\hline \multirow[t]{2}{*}{ Specific non-employment (\%) } & & & -0.001 & & & $0.006^{* * *}$ \\
\hline & & & $(0.005)$ & & & $(0.002)$ \\
\hline \multirow{2}{*}{$\begin{array}{l}\text { Unemployment experience } \\
\text { (1-yes, 0-no) }\end{array}$} & 0.115 & $0.154^{*}$ & 0.113 & 0.007 & 0.011 & 0.009 \\
\hline & $(0.073)$ & $(0.081)$ & $(0.080)$ & $(0.034)$ & $(0.033)$ & $(0.033)$ \\
\hline
\end{tabular}

Notes: 1) Standard errors robust to heteroscedasticity, autocorrelation and clusterisation are in parentheses;

2) *** - significance at $1 \%$ level; ** - significance at $5 \%$ level; ${ }^{*}$ - significance at $10 \%$ level; 3) All variables mentioned in Table 4 are controlled; 4) Estimates for constants and cut points are available on request; 5) RU is regional unemployment, SU is specific unemployment, SNE is specific non-employment. 
Table 6 Factors influencing the fear of not finding a new job, RLMS, 1994-2009, oprobit

\begin{tabular}{|c|c|c|c|c|c|c|}
\hline \multirow{2}{*}{$\begin{array}{l}\text { Dependent variable: fear of } \\
\text { not finding a new job (1-min., 5-max) } \\
\text { Variables }\end{array}$} & \multicolumn{3}{|c|}{ 1994-1998 } & \multicolumn{3}{|c|}{$2000-2009$} \\
\hline & $\mathrm{RU}$ & SU & SNE & $\mathrm{RU}$ & SU & SNE \\
\hline \multirow[t]{2}{*}{ Female } & $-0.542^{* * *}$ & $-0.540^{* * *}$ & $-0.535^{* * *}$ & $0.283^{* * *}$ & $0.284^{* * *}$ & $0.231^{* * *}$ \\
\hline & $(0.032)$ & $(0.033)$ & $(0.060)$ & $(0.034)$ & $(0.033)$ & $(0.036)$ \\
\hline \multirow[t]{2}{*}{ Age (years) } & $0.020^{* *}$ & $0.020^{* *}$ & $0.020^{* *}$ & 0.001 & 0.002 & 0.001 \\
\hline & $(0.009)$ & $(0.009)$ & $(0.009)$ & $(0.005)$ & $(0.005)$ & $(0.005)$ \\
\hline \multirow[t]{2}{*}{ Age squared } & -0.000 & -0.000 & -0.000 & $0.000^{* * *}$ & $0.000^{* * *}$ & $0.000^{* * *}$ \\
\hline & $(0.000)$ & $(0.000)$ & $(0.000)$ & $(0.000)$ & $(0.000)$ & $(0.000)$ \\
\hline \multirow[t]{2}{*}{ Receiving pension } & 0.050 & 0.043 & 0.047 & 0.033 & 0.039 & 0.036 \\
\hline & $(0.062)$ & $(0.064)$ & $(0.063)$ & $(0.036)$ & $(0.034)$ & $(0.036)$ \\
\hline \multirow{2}{*}{$\begin{array}{l}\text { Education level: secondary } \\
\text { (reference category: below secondary) }\end{array}$} & 0.016 & 0.023 & 0.019 & $-0.066^{*}$ & -0.056 & $-0.066^{*}$ \\
\hline & $(0.041)$ & $(0.042)$ & $(0.043)$ & $(0.036)$ & $(0.035)$ & $(0.036)$ \\
\hline \multirow[t]{2}{*}{ Vocational } & 0.010 & 0.017 & 0.009 & $-0.101^{* * *}$ & $-0.101^{* * *}$ & $-0.215^{* * *}$ \\
\hline & $(0.042)$ & $(0.040)$ & $(0.061)$ & $(0.029)$ & $(0.030)$ & $(0.051)$ \\
\hline \multirow[t]{2}{*}{ Tertiary } & $-0.092^{* *}$ & $-0.079^{*}$ & -0.105 & $-0.072^{* *}$ & $-0.082^{* *}$ & $-0.339^{* * *}$ \\
\hline & $(0.046)$ & $(0.042)$ & $(0.164)$ & $(0.031)$ & $(0.037)$ & $(0.106)$ \\
\hline \multirow[t]{2}{*}{ Tenure (years) } & $0.010^{* * *}$ & $0.009^{* * *}$ & $0.010^{* * *}$ & $0.023^{* * *}$ & $0.024^{* * *}$ & $0.024^{* * *}$ \\
\hline & $(0.003)$ & $(0.003)$ & $(0.003)$ & $(0.003)$ & $(0.003)$ & $(0.003)$ \\
\hline \multirow[t]{2}{*}{ Tenure squared } & $-0.000^{*}$ & $-0.000^{*}$ & $-0.000^{*}$ & $-0.000^{* * *}$ & $-0.000^{* * *}$ & $-0.000^{* * *}$ \\
\hline & $(0.000)$ & $(0.000)$ & $(0.000)$ & $(0.000)$ & $(0.000)$ & $(0.000)$ \\
\hline \multirow[t]{2}{*}{ Married } & 0.004 & 0.002 & 0.005 & -0.008 & -0.010 & -0.007 \\
\hline & $(0.039)$ & $(0.039)$ & $(0.039)$ & $(0.022)$ & $(0.023)$ & $(0.022)$ \\
\hline \multirow{2}{*}{$\begin{array}{l}\text { Firm size: < } 50 \text { employees } \\
\text { (reference category: >1000 employees) }\end{array}$} & $-0.153^{* * *}$ & $-0.152^{* * *}$ & $-0.153^{* * *}$ & $-0.059^{*}$ & $-0.057^{*}$ & $-0.058^{*}$ \\
\hline & $(0.053)$ & $(0.053)$ & $(0.053)$ & $(0.031)$ & $(0.031)$ & $(0.031)$ \\
\hline \multirow[t]{2}{*}{ 51-100 employees } & $-0.204^{* * *}$ & $-0.195^{* * *}$ & $-0.201^{* * *}$ & 0.033 & 0.024 & 0.030 \\
\hline & $(0.054)$ & $(0.053)$ & $(0.055)$ & $(0.038)$ & $(0.037)$ & $(0.037)$ \\
\hline \multirow[t]{2}{*}{ 101-200 employees } & -0.083 & -0.085 & -0.084 & $0.085^{* * *}$ & $0.079^{* * *}$ & $0.082^{* * *}$ \\
\hline & $(0.059)$ & $(0.059)$ & $(0.060)$ & $(0.027)$ & $(0.027)$ & $(0.027)$ \\
\hline \multirow[t]{2}{*}{ 201-1000 employees } & -0.056 & -0.058 & -0.056 & $0.101^{* * *}$ & $0.098^{* * *}$ & $0.100^{* * *}$ \\
\hline & $(0.044)$ & $(0.042)$ & $(0.044)$ & $(0.028)$ & $(0.029)$ & $(0.028)$ \\
\hline \multirow[t]{2}{*}{ State ownership } & 0.033 & 0.033 & 0.032 & $-0.053^{* *}$ & $-0.051^{* *}$ & $-0.051^{* *}$ \\
\hline & $(0.029)$ & $(0.030)$ & $(0.029)$ & $(0.024)$ & $(0.024)$ & $(0.024)$ \\
\hline \multirow[t]{2}{*}{ Having subordinates } & $-0.108^{* * *}$ & $-0.100^{* * *}$ & $-0.108^{* * *}$ & $-0.115^{* * *}$ & $-0.119^{* * *}$ & $-0.117^{* * *}$ \\
\hline & $(0.036)$ & $(0.035)$ & $(0.036)$ & $(0.016)$ & $(0.016)$ & $(0.015)$ \\
\hline \multirow[t]{2}{*}{ Second job } & $-0.428^{* * *}$ & $-0.437^{* * *}$ & $-0.430^{* * *}$ & $-0.433^{* * *}$ & $-0.425^{* * *}$ & $-0.434^{* * *}$ \\
\hline & $(0.047)$ & $(0.047)$ & $(0.047)$ & $(0.041)$ & $(0.042)$ & $(0.042)$ \\
\hline \multirow[t]{2}{*}{ Rural } & $0.346^{* * *}$ & $0.347^{* * *}$ & $0.352^{* * *}$ & $0.511^{* * *}$ & $0.498^{* * *}$ & $0.525^{* * *}$ \\
\hline & $(0.070)$ & $(0.072)$ & $(0.071)$ & $(0.097)$ & $(0.100)$ & $(0.097)$ \\
\hline \multirow[t]{2}{*}{ Moscow or St. Petersburg } & $-0.236^{* *}$ & $-0.247^{* *}$ & $-0.245^{* *}$ & -0.008 & -0.095 & -0.126 \\
\hline & $(0.100)$ & $(0.102)$ & $(0.099)$ & $(0.103)$ & $(0.082)$ & $(0.077)$ \\
\hline \multirow[t]{2}{*}{ Wage arrears } & $0.133^{* * *}$ & $0.139 * * *$ & $0.136^{* * *}$ & -0.002 & 0.003 & 0.005 \\
\hline & $(0.026)$ & $(0.027)$ & $(0.027)$ & $(0.031)$ & $(0.032)$ & $(0.031)$ \\
\hline
\end{tabular}


Table 6 Factors influencing the fear of not finding a new job, RLMS, 1994-2009, oprobit (Continued)

\begin{tabular}{|c|c|c|c|c|c|c|}
\hline Regional unemployment (\%) & 0.007 & & & $0.022^{* *}$ & & \\
\hline & $(0.016)$ & & & $(0.011)$ & & \\
\hline \multirow[t]{2}{*}{ Specific unemployment (\%) } & & -0.000 & & & 0.002 & \\
\hline & & $(0.003)$ & & & $(0.002)$ & \\
\hline \multirow[t]{2}{*}{ Specific unemployment (\%) } & & & 0.000 & & & $0.005^{* * *}$ \\
\hline & & & $(0.004)$ & & & $(0.002)$ \\
\hline $\mathrm{N}$ & 11369 & 10998 & 11332 & 48187 & 46463 & 48187 \\
\hline
\end{tabular}

Notes: 1) Standard errors robust to heteroscedasticity, autocorrelation and clusterisation are in parentheses;

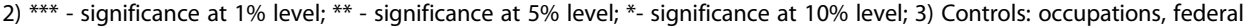
districts and years; 4) Estimates for constants and cut points are available on request; 5) RU is regional unemployment, $\mathrm{SU}$ is specific unemployment, SNE is specific non-employment.

\subsection{Robustness of estimates}

We also test alternative specifications, excluding all those variables that are potentially endogenous. Though our unemployment variables are exogenous and are not associated with individual and job characteristics, their coefficients estimates can be potentially contaminated by endogeneity of characteristics as firm size, type of labor contract, job tenure, exposure to wage arrears, among others. Estimation of this reduced specification gives basically unchanged results for unemployment coefficients (in order to save space here, we do not present these estimates, but they are available upon request).

As an alternative robustness check, we estimated our regressions separately for groups of workers with different employment protections. One could expect that unemployment would have a smaller effect on fears if jobs are well protected. In order to differentiate workers by job security, we used two major criteria, ownership (state vs. private) and firm size (fewer than 50 workers vs. over 500 workers), and their interaction. We assume that employment protection in small private firms is weaker than in large state-owned companies. (However, if we assume that large firms offer better employee-employer match, then the impact of firm size on fear can be positive). We find that the impact of unemployment on fears remains insignificant in all sub-samples (the

Table 7 Personal unemployment experience and fear of not finding a new job, RLMS, 1994-2008, oprobit

\begin{tabular}{|c|c|c|c|c|c|c|}
\hline \multirow{2}{*}{$\begin{array}{l}\text { Dependent variable: fear of not } \\
\text { finding a new job } \\
\text { (1-min., 5-max.) }\end{array}$} & \multicolumn{3}{|c|}{ 1994-1998 } & \multicolumn{3}{|c|}{$2000-2008$} \\
\hline & $\mathrm{RU}$ & SU & SNE & $\mathrm{RU}$ & SU & SNE \\
\hline \multirow[t]{2}{*}{ Regional unemployment (\%) } & 0.011 & & & $0.023^{* *}$ & & \\
\hline & 0.018 & & & 0.011 & & \\
\hline \multirow[t]{2}{*}{ Specific unemployment (\%) } & & 0.001 & & & 0.002 & \\
\hline & & 0.003 & & & 0.002 & \\
\hline \multirow[t]{2}{*}{ Specific non-employment (\%) } & & & 0.001 & & & $0.005^{* * *}$ \\
\hline & & & 0.004 & & & 0.002 \\
\hline \multirow[t]{2}{*}{$\begin{array}{l}\text { Unemployment experience } \\
\text { (1-yes, } 0 \text {-no) }\end{array}$} & $0.154^{* *}$ & $0.169^{* *}$ & $0.150^{* *}$ & $0.074^{* * *}$ & $0.084^{* * *}$ & $0.078^{* * *}$ \\
\hline & 0.072 & 0.077 & 0.072 & 0.023 & 0.025 & 0.024 \\
\hline
\end{tabular}

Notes: 1) Standard errors robust to heteroscedasticity, autocorrelation and clusterisation are in parentheses;

2) *** - significance at $1 \%$ level; ** - significance at $5 \%$ level; ${ }^{*}$ - significance at $10 \%$ level; 3) All variables mentioned in Table 4 are controlled; 4) Estimates for constants and cut points are available on request; 5) RU is regional unemployment, SU is specific unemployment, SNE is specific non-employment. 
estimates are available on request). This result seems unexpected and may suggest that fearfulness causes implicit sorting of workers across protected and non-protected jobs.

The fact that estimates are stable over time also point to their robustness. Since we consider the long period (1994-2009) that includes different sub-periods with contrasting macroeconomic regimes, the impact of actual unemployment could vary over time. Though coefficients are insignificant on the pooled sample, they may be significant for particular years. We show the corresponding estimates in Table 8. For convenience of comparison, we also present the estimates for both pooled sub-periods. In any year of the first sub-period, the effect of unemployment on either fear was insignificant and close to the estimate on the pooled sample. In the second sub-period, the impact of regional unemployment on fear of losing job was insignificant in 7 cases of 10, the impact of group-specific unemployment was insignificant in 9 cases of 10, and the impact of group-specific non-employment was insignificant in 6 cases of 10. The same outcomes were observed for fear of not finding a job. These results indicate that our estimates based on the pooled data reflect inter-temporal story quite correctly.

\subsection{Dynamics of fears}

Our equations include another important parameter that consistently retains a high value in all specifications. This is the time effect (year of the survey). Being purged of the influence of individual characteristics, characteristics of jobs and unemployment rates, it can be interpreted as reflecting the influence of the social atmosphere in the society in the given year. If comparing actual unemployment with a thunderstorm (the latter can be stronger or weaker), then the time effect can be compared with expectation of a

Table 8 Effects of unemployment on the fear of losing a job and on the fear of not finding a new job, by yearly cross-sections, RLMS, 1994-2009

\begin{tabular}{lccccccc}
\hline \multicolumn{3}{c}{ Fear of losing a job } & \multicolumn{3}{c}{ Fear of not finding a new job } \\
\hline 1994 & RU & SU & SNE & & RU & SU & SNE \\
1995 & -0.031 & -0.009 & -0.004 & 1994 & 0.003 & -0.004 & 0.006 \\
1996 & 0.004 & 0.003 & -0.001 & 1995 & 0.039 & 0.007 & -0.003 \\
1998 & -0.024 & -0.004 & 0.001 & 1996 & 0.008 & -0.001 & -0.003 \\
$1994-1998$ & -0.003 & -0.003 & -0.002 & 1998 & 0.015 & -0.001 & 0.004 \\
2000 & -0.015 & -0.004 & -0.002 & $1994-1998$ & 0.007 & 0.000 & 0.000 \\
2001 & -0.023 & -0.002 & 0.006 & 2000 & -0.010 & -0.006 & 0.002 \\
2002 & 0.010 & -0.005 & -0.002 & 2001 & $0.043^{* *}$ & -0.002 & 0.001 \\
2003 & 0.039 & 0.007 & $0.009^{* *}$ & 2002 & 0.028 & -0.000 & 0.004 \\
2004 & $0.040^{*}$ & $0.010^{*}$ & $0.015^{* * *}$ & 2003 & 0.025 & $0.011^{* *}$ & $0.012^{* * *}$ \\
2005 & 0.019 & 0.003 & $0.014^{* * *}$ & 2004 & 0.019 & 0.002 & 0.006 \\
2006 & $0.030^{*}$ & 0.002 & $0.007^{*}$ & 2005 & $0.035^{* *}$ & 0.004 & $0.007^{* *}$ \\
2007 & $0.033^{*}$ & 0.004 & 0.002 & 2006 & $0.044^{* * *}$ & 0.005 & 0.003 \\
2008 & 0.012 & 0.005 & 0.004 & 2007 & 0.019 & 0.007 & $0.010^{* * *}$ \\
2009 & 0.004 & -0.003 & 0.003 & 2008 & $0.043^{* *}$ & 0.000 & $0.011^{* * *}$ \\
$2000-2009$ & -0.001 & -0.002 & -0.002 & 2009 & 0.008 & -0.002 & 0.002 \\
\hline
\end{tabular}

Notes: ${ }^{* * *}$ - significance at $1 \%$ level; ${ }^{* *}$ - significance at $5 \%$ level; ${ }^{*}$ - significance at $10 \%$ level. RU is regional unemployment, SU is specific unemployment, SNE is specific non-employment. 
thunderstorm. The expectations can be shaped by scientific forecasts as well as by erroneous information based on prejudices. Meanwhile, these erroneous visions can be deliberately disseminated, or they can evolve spontaneously. In this sense, the time effect in our setting is a measure of social stability in the society in the given year as an expectation of an unemployment "thunderstorm" that may never occur.

Figure 4 presents yearly changes in unconditional averages for fear (dotted lines) as well as conditional time effects (continuous lines) over the whole period of 1994-2008. In 1994-2001, the latter were slightly below the unconditional averages, but they switched places in 2005-08. In the beginning of the period, the unconditional averages overestimated the effect of time on fears, but underestimated the effect later on.

Fears reached peak levels in the crisis-ridden year of 1998, then weakened by 2001 and stayed at the same levels since then. In 2002, the new Labor Code did not cause any change in fear levels. From 2001 to 2007, fear of losing job stayed almost intact with insignificant fluctuations. Fears associated with job search changed little in 2001-05 but weakened further in 2006-07. A change in the trend happened in 2008 against the background of the economic crisis. Estimates for time effects as proxies for social stability increased dramatically, signaling that the population expected a strong "thunderstorm". Note that this was an expectation only, since the "thunderstorm" itself (as a catastrophic level of unemployment) passed by and touched the population only marginally and somewhat later. The RLMS data were collected largely in October and November, while a major increase in unemployment was captured by statistics only in early 2009. In November 2008, the unemployment rate equaled a modest $7 \%$, the level of 2004-05. These years were considered quite successful from the labor market point of view. Such impulsive and early reactions of fear to unemployment which had not occurred yet indicates that Russian people have low trust in social protection institutions and hardly believe that the state support may be effective if actual unemployment rises.

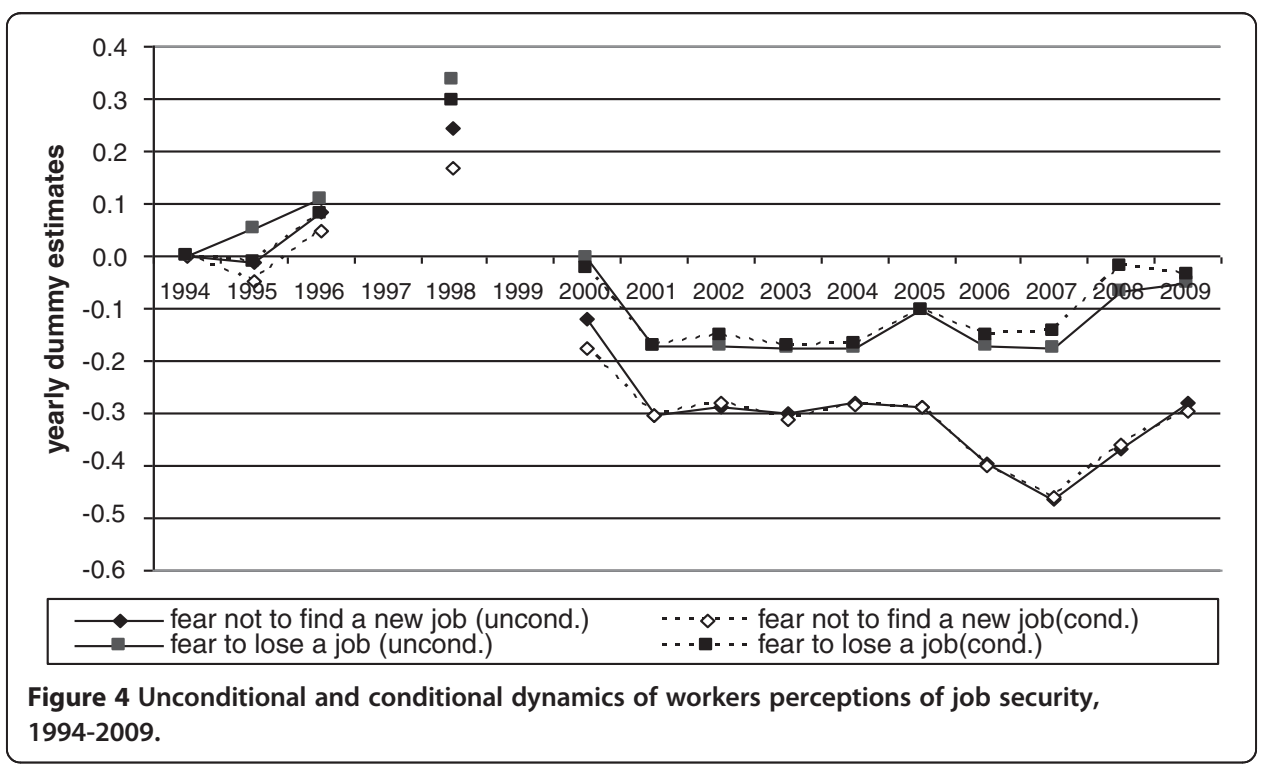




\section{Impact of unemployment: how large is it?}

The data presented above allows us to conclude that actual unemployment does not unambiguously emerge as a strong factor generating fear of unemployment, though in a few specifications its effect is statistically significant. Given specific features of the ordered probit model, we cannot interpret the coefficients as explicit elasticities. In order to get some sense of practical effect of unemployment on fear, we calculate conditional probabilities of choosing various positions on the fear scales. We let unemployment vary while keeping all other right hand variables equal to sample means.

Since between-group and over-time variation in choosing the position 4 is quite small, we focus on choosing the position 5 which is more sensitive to changes in external factors. Estimated differences in average conditional probabilities for choosing pos. 5 for all unemployment variables, given that individual and job characteristics are controlled for, are presented on Figure 5-6. Let us assume that the unemployment level changed instantly from its rate that was equal to the 25th percentile in the distribution to the rate of the $75^{\text {th }}$ percentile, given that all other characteristics are fixed. This would be a very large and shocking change in the labor market. In the first sub-period, this simulated jump would transfer our respondents from a labor market with specific unemployment of $6,6 \%$ into the market with $14,1 \%$ of unemployment. However, the probability of entering the group with the maximal level of fear would hardly change (see Figure 5). In other words, the reaction to change in external environment would be very weak (but negative!). One could speculate that in the 1990s, the Russians faced the unemployment problem for the first time in their personal life and had little experience in dealing with it. The increase in unemployment in that period was accompanied for the population with intensive social learning that led to forming more rational perceptions.

In the second sub-period, the effect of unemployment on the fear of job loss became positive but remained very little in its magnitude. At that time, the unemployment in

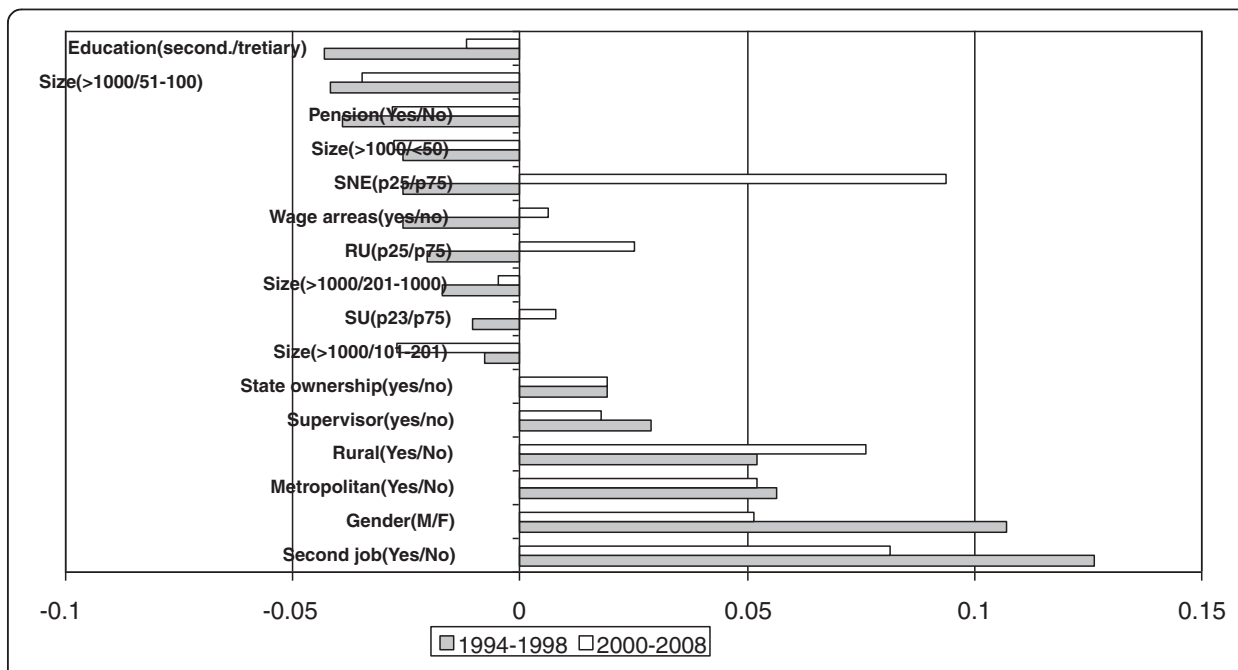

Figure 5 Effects of different factors on the probability to choose value " 5 " (very concerned) when answering the question on the fear of losing a job. 


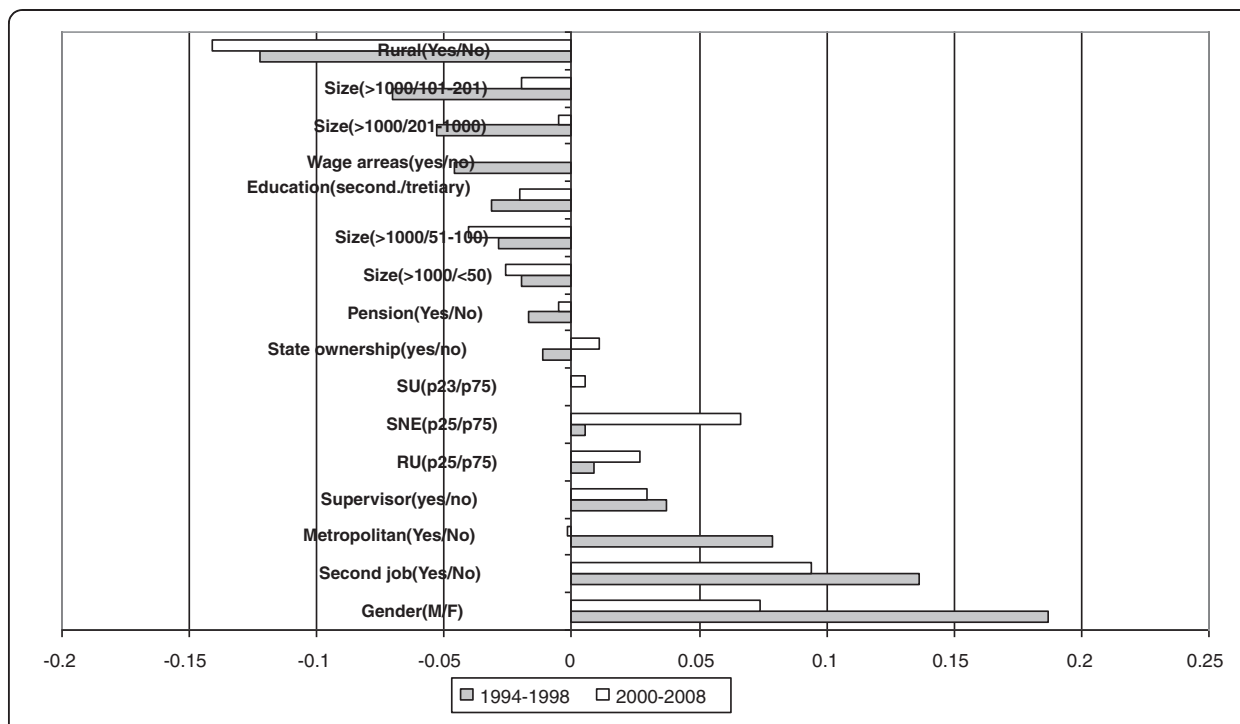

Figure 6 Effects of different factors on the probability to choose value " 5 " (very concerned) when answering the question on the fear of not finding a new job.

Russia declined. Its move from $14,1 \%$ to $4,3 \%$ would cause a decrease in conditional probability for fear of losing job by a hardly visible $0,08 \mathrm{pp}$.

How did the fear of not finding a job react? This reaction would also be very subtle. In the first sub-period, an increase in regional unemployment from 7,9 to $11,5 \%$ would increase conditional probability of the maximal level of fear from $36,6 \%$ to $37,5 \%$, or less than by 1 pp. However, a change in the specific unemployment from 6,6\% to $14,1 \%$ would cause no effect on the level of fear. An increase in the specific non-employment from 24,9 to $68,4 \%$ would increase probability of the fear by $0,5 \mathrm{pp}$. In the second sub-period, the reaction of interest remained weak. Thus, doubling the regional unemployment was associated with an increase in the probability of fear of not finding a job by $2,7 \mathrm{pp}$ (from 19,2 to $21,9 \%$ ). The response from the specific unemployment was much weaker: a jump in unemployment from $4,3 \%$ to $13,2 \%$ caused an increase in the probability by just $0,5 \mathrm{pp}$. However, tripling the specific non-employment rate (from $26,9 \%$ to $75,7 \%$ ) increased this probability by $6,8 \mathrm{pp}$. Note that all these simulated changes in labor market conditions are dramatic and unrealistically large in their magnitude. This serves as an additional illustration for the fact that expected reactions of unemployment on fears remain weak in practical terms, even if they are statistically significant. $^{24}$

\section{Conclusions}

Using Russian household survey data (RLMS) for 1994-2009, we detect that the Russians tend to have very articulated fears of losing their jobs and not finding new ones of comparable worth. Our comparisons show that such fear indexes are much higher than in the OECD countries and are close to that is observed in Latin American countries with weak social protection systems. This indicates that Russian workers perceive the actual state of job security as weak. 
What affects these fears? We look at three groups of variables: i) individual characteristics of workers, ii) job-related characteristics, and iii) labor market characteristics. Better-educated workers, younger workers, men, and urban workers feel better protected, other things being equal. Having an alternative income source in a form of pension or second job serves as an additional protection. These effects do not come as a surprise. The effects of job characteristics seem to be less obvious. Working at a small or medium-sized firm weakens fears, though employment in small firms is usually more flexible and less protected. The effect of state ownership is ambiguous, but it is small even if it is protective. We cannot exclude the possibility that more fearful workers preselect themselves into better-protected jobs. If sorting of this type actually takes place, the observed level of fear is lower than it otherwise could be. We also confirm the findings which were noted earlier in other papers on Russia and which diverge from the findings on other countries (that women tend to express stronger fears and that the fearfulness increases with tenure).

Our main finding is that the fear of unemployment on the Russian labor market is only loosely associated with actual unemployment. One could expect that subjective perceptions should reflect fluctuations of unemployment rates. In fact, they are usually closely associated in the OECD countries, but in Russia this association is not strong if exists at all. Having estimated various specifications for different sub-periods and on various subsamples, we have not found statistically strong association between individual fears of unemployment and actual local unemployment, including that among peers. Even if coefficients for unemployment (as they are in some specifications) are statistically significant, its practical impact remains small. The simulation of contrast changes in unemployment rates does not induce significant changes in the fears.

Very high and persistent level of fear of unemployment against the background of rapid economic growth and fast labor market recovery raises the issue of what causes fearfulness in Russia. We may speculatively suggest two potential (and not mutually exclusive) fruitful directions for such study.

The first direction is motivated by the recent paper on the geography of fear (Treisman, 2011). Treisman argues that partial fears are inter-correlated and some countries are more fearful than others, while the actual risks that population is facing often do not emerge as a cause of the fearfulness. Russia is not included in the Treisman's sample but high intensity and persistence of fears can be explained through strong predisposition to fears.

The second direction is related to the stream of literature arguing that personal experience in the past may affect future behavior and subjective perceptions (e.g., Giuliano and Spilimbergo, 2009; Malmendier and Nagel, 2011). The Russian population experienced very strong shocks in the late 1980s and early 1990s that might leave deep mental scars supporting their fear of unemployment.

In the meantime, high and persistent fears may have important politico-economic implications. Given the strong fear of unemployment in the population, any economic reform that affects allocation of labor may face additional resistance. Politicians reacting to subjective perceptions of voters are likely to freeze reforms if the latter are likely to cause more labor market volatility. Therefore, the workers' fear of unemployment becomes the politicians' fear and may stimulate the government to populist political actions. This, in turn, threatens to further reduce the number of protected jobs, thus causing even stronger fear. 


\section{Endnotes}

${ }^{1} \mathrm{Al}$ Gore. The Politics of Fear. Social Research Vol 71: No 4, Winter 2004, p. 788.

${ }^{2}$ Scared people are more likely to abandon human rights and democracy while authoritarian-style politicians are eager to use this. But even in stable democracies, fears can easily be politically used and misused. An example of such use of fear is the fight against terrorism in the USA after 9/11. (See more in: Fear: Its Political Uses and Abuses, Social Research, 2004). In Russia, we observed the same sort of political use and misuse in Russia after the terrorist attacks in Moscow or Beslan when Russians easily gave up their civil rights and freedoms.

${ }^{3}$ For example, the Russian government, being afraid of social protests and of losing popularity as a consequence of mass displacements, was ready to bail out potentially bankrupt firms. In September 2009, the largest Russian carmaker AVTOVAZ announced forthcoming mass layoffs (staff cuts by 30\%). The government intervened immediately to ban these plans, since it was afraid of the social and political consequences [Vedomosti, 9.10.09]. As a result, the firm received a massive financial bailout.

${ }^{4}$ This indicator jumped up to $28 \%$ in 2009 .

${ }^{5}$ As a note, the authors have never shared this opinion. See Gimpelson et al. (2010b).

${ }^{6}$ There is no consensus in the literature whether the Russian EPL can be considered rigid. According to OECD (2011) and Muravyev (2010), Russia's EPL is not stringent compared to the OECD average. Kapeliushnikov (2011) evaluates it as much more stringent that the OECD average. However, all seem to agree that the regulation of permanent contracts is excessively stringent. The disagreement concerns the evaluation of stringency in relation to fixed-term contracts and temporary work agencies (for more details see Kapeliushnikov, 2011). The authors of this paper share the opinion that actual rules are excessively rigid given formal legal regulations as well as judicial practice and extralegal governmental interventions.

${ }^{7}$ On EPL enforcement in Russia see: Gimpelson et al. (2010).

${ }^{8}$ Unemployment benefits were raised notably in the beginning of 2009 as an anticrisis measure.

${ }^{9}$ Each of the fear questions allows for five alternative responces ranked from 1 (the lowest level of fear) to 5 (the highest level). For more details about the RLMS and variables used in this study see Section 3.

${ }^{10}$ This goes in line with the cross-country studies showing a negative relationship between EPL strictness and subjective perceptions of job security (see, for example, Clark and Postel-Vinay 2009).

${ }^{11}$ This situation is somewhat similar to the relationship between the level of trust in the society and demand for the state regulation which are also positively associated (see Aghion, Ph., Y.Algann, P.Cahuc and Shleifer 2009).

${ }^{12}$ These can be various time-related events like legislative amendments that may change the general regulatory framework, or increased public awareness disseminated by media.

${ }^{13}$ Initially the second question scale was designed in the opposite way. For convenience, we converted it to make higher scores mean stronger fear.

${ }^{14}$ Gimpelson et al. (2003) used the index that was equaled to the sum of both variables. Linz and Semykina (2008) used these questions separately.

${ }^{15} \mathrm{We}$ are grateful to the anonymous referee, who emphasized this issue. 
${ }^{16}$ Smyth and Taylor (1992) studied the impact of unemployment on the popularity of the US Presidents. They argue that respondents pay attention to the unemployment in their peer groups as well as unemployment at the national level.

${ }^{17}$ We have to admit that the RLMS data does not capture periods between survey rounds and therefore does not allow reconstructing a worker's complete history. This can lead to underestimation of actual unemployment experience.

${ }^{18} \mathrm{We}$ cannot exclude endogeneity of some individual and job characteristics to the fear of unemployment. It can be caused by unobservables affecting observable characteristics in the Eq. (1) as well as the fear variables. Another reason is in potential sorting of workers, in which those workers who are more fearful will seek more protected jobs. However, neither reason may affect estimates of coefficients for actual aggregate unemployment.

${ }^{19}$ About labor market sorting see, for example, Krueger and Schkade (2008).

${ }^{20}$ Gimpelson and Monusova (2009).

${ }^{21}$ Methodologically, this process is very close to what was done by Linz and Semykina (2008) on the RLMS data. At this stage, the distinction of our work is that it uses additional variables and longer period of time. Our estimates for specifications similar to those used by Linz and Semykina (2008) are almost identical.

${ }^{22} \mathrm{We}$ do not present tables with these findings for the sake of saving space. The informal sector dummies are available for selected years only.

${ }^{23}$ The changing direction of influence coincides with findings from other studies, e.g. Gimpelson et al. (2003) and Linz and Semykina (2008). This can be interpreted as an outcome of intensive social learning that took place during the period.

${ }^{24}$ In Linz and Semykina (2008, p. 452), a twofold increase in regional unemployment (from $6 \%$ to $12 \%$ ) the conditional probability of choosing high fear scores $(4+5)$ rose by 2 pp (from 0,60 to 0,62 ) only in $1995-98$, by 5 pp (from 0,55 to 0,60 ) in 2000-04.

\section{Competing interests}

The "IZA Journal of Labor and Development" is committed to the IZA Guiding Principles of Research Integrity. The authors declare that they have observed these principles.

\section{Acknowledgement}

The authors acknowledge financial support from the Volkswagen Foundation within the project "The Political Economy of Labor Market Reform in Transition Countries" and from the Program of Fundamental Studies of HSE. The authors are grateful to R. Kapeliushnikov, H. Lehmann, A. Lukiyanova, M. Lokshin, D. Treisman, A. Zaiceva, and to an anonymous referee for comments and suggestions.

Responsible editor Hartmut Lehmann.

\section{Author details}

${ }^{1}$ Centre for Labor Market Studies, National Research University Higher School of Economics, IZA, Moscow, Russia.

${ }^{2}$ Centre for Labor Market Studies, National Research University Higher School of Economics, Moscow, Russia.

Received: 18 September 2012 Accepted: 21 November 2012

Published: 31 December 2012

\section{References}

Aaronson D, Sullivan D (1998) The Decline of Job Security in the 1990s: Displacement, Anxiety, and Their Effect on Wage Growth. Economic Perspectives 1998(Q1):17-43

Aghion P, Algann Y, Cahuc P, Shleifer A (2009) Regulation and Trust, NBER No.14648

Benito A (2006) Does Job Insecurity Affect Household Consumption? Oxford Economic Papers 58(1):157-181

Blanchflower D (1991) Fear, Unemployment and Pay Flexibility. Economic Journal 101(406):483-496

Blanchflower D, Shadforth C (2007) Fear, Unemployment and Migration, NBER Working Paper No. 13506

Burchell B (1994) The Effects of Labor Market Position, Job Insecurity and Unemployment on Psychological Health. In: Gallie D, Marsh C, Vogler C (eds), Social Change and the Experience of Unemployment Oxford University Press, Oxford, pp 188-212

Burgard S, Brand J, House J (2009) Perceived Job Insecurity and Worker Health in the United States. Social Science and Medicine 69(5):655-802 
Campbell D, Carruth A, Dickerson A, Green F (2007) Job Insecurity and Wages. The Economic Journal 117(518):544-566 Clark A, Postel-Vinay F (2009) Job Security and Job Protection. Oxford Economic Papers 61(2):207-239

Dominitz L, Manski C (1996) Perceptions of Economic Insecurity: Evidence from the Survey of Economic Expectations, NBER Working Paper No. 5690

Elman C, O'Rand A (2002) Perceived Job Insecurity and Entry into Work-Related Education and Training among Adult Workers. Social Science Research 31:49-76

Fear: Its Political Uses and Abuses (2004) Social Research, Special Issue, vol.71, No.4

Fullerton A, Wallace M (2007) Traversing the flexible turn: US workers' perceptions of job security, 1977-2002. Social Science Research 36(1):201-221

Gimpelson V, Kapeliushnikov R, Ratnikova T (2003) The Fear of Unemployment and Wage Flexibility in Russia. HSE Economic Journal 7(3):341-370 (in Russian)

Gimpelson V, Monusova G (2009) The Fear of Unemployment and Labor Market Behaviour: International Comparisons, HSE Working Paper WP3/2009/04 (in Russian)

Gimpelson V, Kapeliushnikov R, Lukiyanova A (2010a) Employment Protection Legislation in Russia: Regional Enforcement and Labor Market Outcomes. Comparative Economic Studies 52(4):611-636

Gimpelson V, Kapeliushnikov R, Lukiyanova A (2010b) Stuck Between Surplus and Shortage: Demand for Skills in the Russian Industry. Labor 24(3):311-332

Gimpelson V, Kapeliushnikov R (2011) Labor Market Adjustment: Is Russia Different? IZA DP 5588

Giuliano P, Spilimbergo A (2009) Growing Up in a Recession: Beliefs and the Macroeconomy, NBER WP No.15321

Gore A (2004) The Politics of Fear. Social Research 71(4):779-798

Graham C (2002) Public Attitudes Matter: A Conceptual Frame for Accounting for Political Economy in Safety Nets and Social Assistance Policies, The World Bank, SPDP Series No.0233

Green F, Felstead A, Burchell B (2000) Job Insecurity and the Difficulty of Regaining Employment: An Empirical Study of Unemployment Expectations, Oxford Bulletin of Economics and Statistics, Vol. 62, Special Issue

Kapeliushnikov R (2011) How to measure EPL stringency for Russia: A comment, HSE Working Paper WP3/2011/02 (in Russian)

Krueger A, Schkade D (2008) Sorting in the Labor Market. Do Gregarious Workers Flock to Interactive Jobs? The Journal of Human Resources 43(4):859-883

Lehmann H, Razzolini T, Zaiceva A (2011) Job Separations and Informality in the Russian Labor Market, / IZA DP No.6230

Linz S, Semykina A (2008) How do workers fare during transition? Perceptions of job insecurity among Russian workers, 1995-2004. Labor Economics 15(3):442-458

Manski C, Straub J (2000) Worker Perceptions of Job Insecurity in the Mid-1990s: Evidence from the Survey of Economic Expectations. The Journal of Human Resources 35(3):447-479

Malmendier U, Nagel S (2011) Depression Babies: Do Macroeconomic Experiences Affect Risk Taking? The Quarterly Journal of Economics 126:373-416

Muravyev A (2010) Evolution of Employment Protection Legislation in the USSR, CIS and Baltic States, 1985-2009, IZA Discussion Paper No. 5365

OECD (1997) Is Job Security on the Increase in OECD Countries? / Chapter 5 in OECD Employment Outlook. OECD, Paris, p 1997

OECD (2011) Reviews of Labor Market and Social Policies: Russian Federation. OECD, Paris, p 2011

Schmidt S (1999) Long-Run Trends in Workers' Beliefs about Their Own Job Security: Evidence from the General Social Survey. Journal of Labor Economics 17, No. 4, Part 2: Changes in Job Stability and Job Security (Oct., 1999), S127-S141

Smyth D, Taylor S (1992) Do group-specific or national unemployment rates influence perceptions? Journal of Economic Behavior and Organization 19(3):379-388

Stephens M (2004) Job Loss Expectations, Realizations, and Household Consumption Behavior. Review of Economics and Statistics 86(4):253-269

Treisman D (2011) The Geography of Fear, NBER WP No.16838

Wasmer E (2006) The Economics of Prozac: Do Employees Really Gain from Strong Employment Protection? IZA DP No.2460

doi:10.1186/2193-9020-1-6

Cite this article as: Gimpelson and Oshchepkov: Does more unemployment cause more fear of unemployment? IZA Journal of Labor \& Development 2012 1:6.

\section{Submit your manuscript to a SpringerOpen ${ }^{\circ}$} journal and benefit from:

- Convenient online submission

- Rigorous peer review

- Immediate publication on acceptance

- Open access: articles freely available online

- High visibility within the field

- Retaining the copyright to your article

Submit your next manuscript at $\boldsymbol{\nabla}$ springeropen.com 